\title{
Petrographic and isotopic evidence for late-stage processes in sulfuric acid caves of the Guadalupe Mountains, New Mexico, USA
}

\author{
Margaret V. Palmer ${ }^{1^{*}}$ and Arthur N. Palmer ${ }^{2}$
}

\begin{abstract}
:
Palmer M.V. and Palmer A.N. 2012. Petrographic and isotopic evidence for late-stage processes in sulfuric acid caves of the Guadalupe Mountains, New Mexico, USA. International Journal of Speleology, 41(2), 231-250. Tampa, FL (USA). ISSN $0392-6672$. http://dx.doi.org/10.5038/1827-806X.41.2.10

Caves of the Guadalupe Mountains have experienced many modifications since their final phase of sulfuric acid speleogenesis several million years ago. Petrographic and geochemical data reveal details of the change from $\mathrm{H}_{2} \mathrm{SO}_{4}$ to $\mathrm{CO}_{2}$-dominated reactions. The $\mathrm{H}_{2} \mathrm{SO}_{4}$ dissolution front acquired a coating of replacement gypsum with local pockets of anhydrite and by-products of altered clay, including Fe-Mn oxides. Alteration of bedrock beneath the gypsum produced a white micritized rind with small negative shifts in $\delta^{13} \mathrm{C}$ and $\delta^{18} \mathrm{O}$. Solution basins contain records of the earliest post-speleogenetic processes: corroded bedrock, residual anhydrite, Fe-Mn oxides from fluctuating $\mathrm{pH}$ and $\mathrm{Eh}$, mammillary calcite, and dolomitization. Later meteoric water removed or recrystallized much of the gypsum and early micrite, and replaced some gypsum with calcite. Mammillary crusts demonstrate fluctuating groundwater, with calcite layers interrupted by films of Fe-Mn oxides precipitated during periodic inflow of anoxic water. Condensation moisture (from local evaporation) absorbs $\mathrm{CO}_{2}$ from cave air, corroding earlier features and lowering their $\delta^{13} \mathrm{C}$ and $\delta^{18} \mathrm{O}$. Drips of condensation water deposit minerals mainly by evaporation, which increases $\delta^{18} \mathrm{O}$ in the speleothems while $\delta^{13} \mathrm{C}$ remains nearly constant. By forcing calcite precipitation, evaporation raises the $\mathrm{Mg}$ content of remaining water and subsequent precipitates. Dolomite (both primary and replacive) is abundant. In areas of low air circulation, water on and within carbonate speleothems equilibrates with caveair $\mathrm{CO}_{2}$, causing minerals to recrystallize with glassy textures. Fluorite on young evaporative speleothems suggests a recent release of deep-source HF gas and absorption by droplets of condensation water.
\end{abstract}

Keywords: sulfuric acid caves; isotopes; petrography; dolomitization; condensation

Received 19 February 2012; Revised 17 April 2012; Accepted 19 April 2012

\section{INTRODUCTION}

Caves of sulfuric acid origin retain diagnostic minerals and features that allow reconstruction of their geochemical history (Polyak \& Provencio, 2001). This paper centers on caves in the Guadalupe Mountains, New Mexico, specifically their latest transition from $\mathrm{H}_{2} \mathrm{SO}_{4}$ speleogenesis to processes dominated by $\mathrm{CO}_{2}$ equilibria. Much cave research today yields paleoclimate data from meteoric speleothems (Fairchild $\&$ Baker, 2012). Instead, this paper emphasizes processes and features specific to the caves themselves. Such information can help identify former conditions in similar caves, and is useful for organizing future studies of geochronology and paleoclimate.

${ }^{1} 619$ Winney Hill Rd., Oneonta, NY 13820, USA

(arthur.palmer@oneonta.edu)

${ }^{2}$ Dept. of Earth and Atmospheric Sciences, State University of New York, Oneonta, NY 13820, USA

(arthur.palmer@oneonta.edu)
Literature on speleogenesis in the Guadalupes is extensive (e.g., Jagnow, 1979; Davis, 1980; Hill, 1987, 1996; Egemeier, 1987; Queen, 1994, 2009a; Polyak et al., 1998; Palmer \& Palmer, 2000; Northup et al., 2000; DuChene \& Cunningham, 2006). The caves have a complex history of Permian and Mesozoic paleokarst produced by freshwater-saltwater mixing, plus Miocene-Pliocene sulfuric acid speleogenesis driven by $\mathrm{H}_{2} \mathrm{~S}$ from reduction of sulfates by petroleum. Argon dating of alunite $\left[\mathrm{KAl}_{3}\left(\mathrm{SO}_{4}\right)_{2}(\mathrm{OH})_{6}\right]$, a by-product of sulfuric acid alteration of clay, reveals four major periods of cave enlargement at different levels from 12 to $4 \mathrm{Ma}$ (Polyak et al., 1998).

\section{FIELD SITES}

The Guadalupe Mountains form a high dissected plateau in semi-arid southeastern New Mexico and western Texas, USA (Fig. 1). They consist of Permian carbonates of the Capitan reef and correlative back-reef strata. The Delaware Basin to the southeast contains fore-reef carbonates capped by thick evaporites. The Guadalupes owe their height to late 


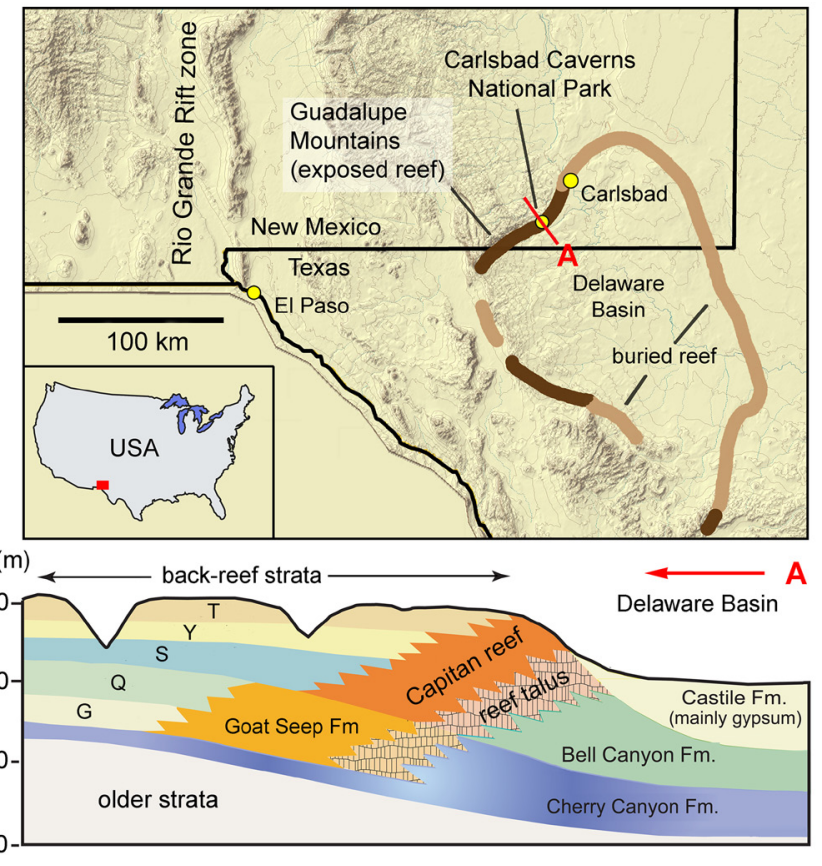

Fig. 1. Location and geologic setting of the Guadalupe Mountains. Back-reef strata: $\mathrm{T}=$ Tansill, $\mathrm{Y}=$ Yates, $\mathrm{S}=$ Seven Rivers, $\mathrm{Q}=$ Queen, $\mathrm{G}=$ Grayburg.

Permian, Mesozoic, and late Cenozoic uplift. Basinal and back-reef strata are prolific petroleum reservoirs. Guadalupe caves typically have ramifying patterns of irregular rooms and mazes, and a combination of steeply ascending and semi-horizontal passages (Fig. 2). Many rooms and passages contain narrow floor fissures that descend tens of meters along fractures and pinch at depth. These appear to have been the main inlets for $\mathrm{H}_{2} \mathrm{~S}$-rich water during speleogenesis.

Three caves in Carlsbad Caverns National Park were investigated (Fig. 2): Carlsbad Cavern has the largest rooms, a surveyed length of $44 \mathrm{~km}$, and verti- cal range of $315 \mathrm{~m}$. Lechuguilla Cave is more complex, with dense arrays of interconnecting passages on many levels, a surveyed length of $210 \mathrm{~km}$, and vertical range of $489 \mathrm{~m}$. The water table is reached in at least two places. Both Carlsbad and Lechuguilla are located mainly in reef and back-reef rocks. Spider Cave is located about midway between the two other caves in the back-reef Yates Formation, a silty dolomitic limestone. It contains $6 \mathrm{~km}$ of maze passages mostly concordant with the bedding, with a vertical range of $41 \mathrm{~m}$.

Cueva de Villa Luz, Tabasco, Mexico, serves as an active analog. It is a sulfuric acid cave in Cretaceous limestone in a tropical rainforest (Hose et al., 2000). It consists of $2 \mathrm{~km}$ of low-gradient stream passages fed by at least 26 groundwater inlets too small to explore. They converge to a spring of 200-300 L $\mathrm{sec}^{-1}$ at $28{ }^{\circ} \mathrm{C}$, slightly above mean surface temperature. Most inlets are anoxic, with $\mathrm{H}_{2} \mathrm{~S}=300-500 \mathrm{mg}$ $\mathrm{L}^{-1}, \mathrm{pH}=6.3-7.1, \mathrm{PCO}_{2}$ up to 0.1 atm, and slight calcite undersaturation. Other inlets are oxygenated and calcite-saturated, with $\mathrm{pH} \sim 7.2$. Bacterial filaments line stream floors - white filaments of sulfur-oxidizing bacteria (e.g., Thiobacillus) in anoxic water, and red filaments of iron bacteria in oxygen-rich waters. A crust of replacive gypsum lines the walls and ceilings. $\mathrm{H}_{2} \mathrm{~S}$ in the cave air has a recorded maximum of 210 ppm, and gas masks are required.

\section{FIELD AND LABORATORY PROCEDURES}

In the three Guadalupe caves, geologic profiles were constructed from the entrances to the deep points with a tripod-mounted Brunton compass and tape, to augment previous maps. The Carlsbad survey extended to Lake of the Clouds (altitude $1007 \mathrm{~m}$ ), perched several tens of meters above the water table. In Lechuguilla the survey extended through several main passages and to the local water table at $~ 962 \mathrm{~m}$. A surface theodolite survey connected the entrances

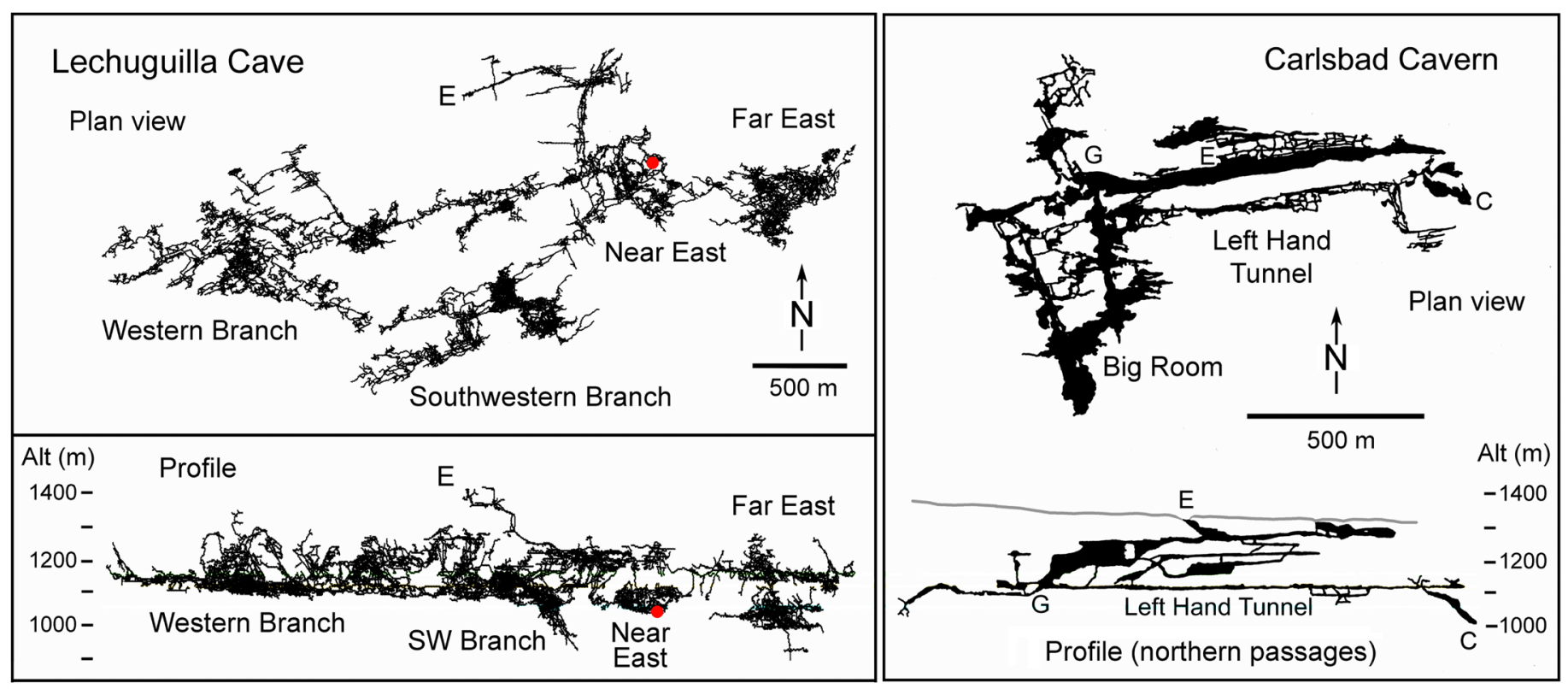

Fig. 2. Maps and profiles of Carlsbad Cavern and Lechuguilla Cave (courtesy of National Park Service). $E=$ entrance; $C=$ Lake of the Clouds; $\mathrm{G}=$ Green Lake Room. Red dot = solution basins studied in Lechuguilla Cave. The Lechuguilla entrance is $5.82 \mathrm{~km}$ WNW of the Carlsbad entrance. The Spider Cave entrance is at $1295 \mathrm{~m}$ asl and $1.81 \mathrm{~km}$ WNW of the Carlsbad entrance. 


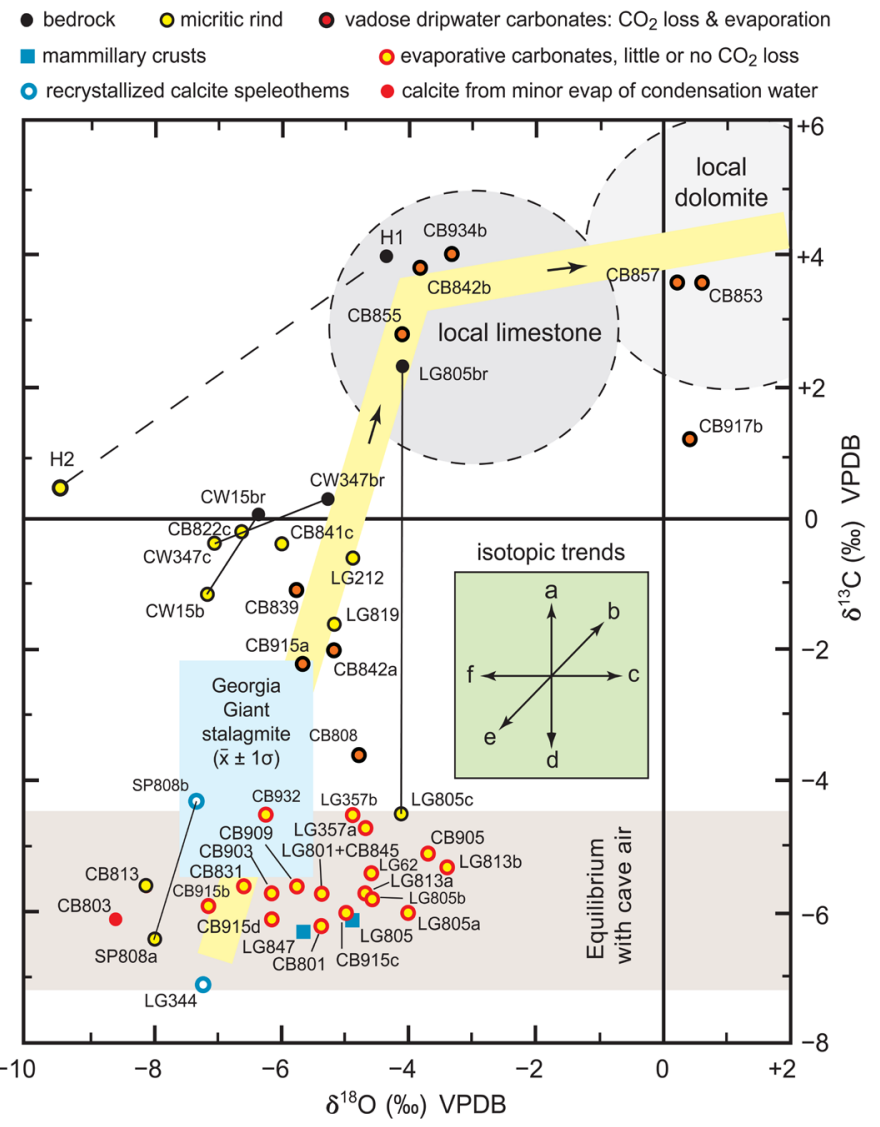

Fig. 3. Carbon-oxygen isotopic ratios of carbonate samples. Arrows in green box show isotopic trends caused by: (a) $\mathrm{CO}_{2}$ degassing in cave, or low water/bedrock ratio of infiltrating water; (b) Degassing and evaporation; (c) Evaporation, low water temperature, or dry climate; (d) Equilibrium with low- $\mathrm{CO}_{2}$ cave air, high water/bedrock ratio, or oxidation of hydrocarbons; (e) Subaerial corrosion, precipitates from condensation water, or high water/bedrock ratio; (f) Wet climate or high water temperature. MS (yellow) $=$ trend of meteoric-water speleothems with increasing $\mathrm{CO}_{2}$ loss and evaporation (additional data in Hill, 1987, and Gonzáles \& Lohmann, 1988). Georgia Giant (blue) = stalagmite in Carlsbad Cavern, mean \pm 1 std dev (Brook et al., 2006). Bedrock data averaged from Hill $(1987,1996)$. See text for details.

and tied to geologic contacts. Bedrock features and minerals were included in the cave mapping, and small naturally broken fragments were obtained for analysis under National Park Service permit. Petrographic relationships were determined from thin-sections, $\mathrm{X}$-ray diffraction, and scanning electron microscopy with energy-dispersive spectroscopy (SEM-EDS). Past chemical reactions were interpreted from mineral associations and $\mathrm{C}-\mathrm{O}$ isotopes (Fig. 3). Mineral stability fields otherwise unavailable were calculated from thermodynamic data listed by Faure (1998). Chemical equilibria were calculated with the software PHREEQC (U.S. Geological Survey).

No numerical dating was done during this phase of our study. Published speleothem dates show much scatter (e.g., Hill, 1987), with many ages beyond the limits of the dating techniques. Asmerom et al. (2007) used U-series dating and $\delta^{18} \mathrm{O}$ values of a stalagmite from Pink Panther Cave ( $25 \mathrm{~km}$ SW of Carlsbad) to distinguish Holocene wet and dry periods. Relatively low $\delta^{18} \mathrm{O}$ correlates with greater rainfall and faster sta- lagmite growth (Fig. 3). The climate was relatively dry from 12 to $7 \mathrm{ka}$ and wetter since. A record of $\delta^{18} \mathrm{O}$ and $\delta^{13} \mathrm{C}$ over the past $164 \mathrm{ky}$ was obtained by Brook et al. (2006) by coring a stalagmite in the Green Lake Room of Carlsbad (Figs. $2 \& 3$ ). It shows five episodes of cold-wet climate separated by warm-dry intervals, with no calcite deposited during the driest intervals. The highest $\delta^{13} \mathrm{C}$ values $(\sim 140-150 \mathrm{ka})$ indicate $\mathrm{CO}_{2}$ degassing, probably during wet periods. $\delta^{18} \mathrm{O}$ values are near the present ideal for calcite deposited by meteoric infiltration (discussed in next section).

\section{WATER CHEMISTRY AND ISOTOPES}

Water infiltrating into Guadalupe caves today has a typical $P \mathrm{CO}_{2}$ of $\sim 0.01$ atm at stalactite tips, which decreases rapidly in mid-air and equilibrates to 0.003-0.0006 atm in pools (additional data in Hill, 1987; Forbes, 2000; Turin \& Plummer, 2000; Gregg Oelker, Altadena, Calif., personal communication, 1990). Incoming water has a high $\mathrm{Mg}+\mathrm{Ca}$ expected of carbonate bedrock and dry climate. In more than half the pools, precipitation of $\mathrm{CaCO}_{3}$ by evaporation and degassing has driven molar $\mathrm{Mg} / \mathrm{Ca}$ above 1.0 , to as much as 6.5. More than $80 \%$ of dripwaters and pools are supersaturated with both calcite and dolomite.

Carbonate samples used for this paper are described in Appendix 1. Their $\delta^{13} \mathrm{C}$ and $\delta^{18} \mathrm{O}$ values are shown in Fig. 3. In the Guadalupes, $\delta^{13} \mathrm{C}$ of $\mathrm{CO}_{2}$ is -20 to $-25 \%$ o VPDB in soil (varies with vegetation type) and about $-15 \%$ in cave air (Gonzáles \& Lohmann, 1988). Typical $\delta^{18} \mathrm{O}$ for local cave water is $-7.9 \pm 1.0 \%$ o VSMOW in drips and $-6.9 \pm 0.7 \%$ in pools, with $\delta^{18} \mathrm{O}$ and $\delta^{2} \mathrm{H}$ near the global meteoric trend (Ingraham et al., 1990); $\delta^{18} \mathrm{O}$ VSMOW $=1.03\left(\delta^{18} \mathrm{O}\right.$ VPDB $)+30.86$ (Faure, 1998, p. 304). Equilibrium of cave $\mathrm{CO}_{2}$ with local bedrock should produce calcite with $\delta^{13} \mathrm{C}$ of about -4.5 to $-7.2 \%$ VPDB (fractionation data from Deines et al., 1974). At the present $14-20{ }^{\circ} \mathrm{C}$ in Guadalupe caves, meteoric water should deposit calcite with $\delta^{18} \mathrm{O}$ about $-7 \pm 0.6 \% \delta^{18} \mathrm{O}$ VPDB (Friedman \& O'Neil, 1977), and $\delta^{18} \mathrm{O}$ of dolomite should be $\sim 2.5 \%$ o greater than that of calcite (Zheng, 1999). Scatter in data probably reflects wet-dry cycles, with wet conditions yielding more negative $\delta^{18} \mathrm{O}$ (Hoy \& Gross, 1982). The cave deposits have isotopes compatible with modern conditions, so no great environmental change is likely since they formed.

The green inset in Fig. 3 shows the major variables that affect the isotopic ratios of carbonate cave deposits. The following trends are of most concern in this paper: As infiltrating meteoric water releases $\mathrm{CO}_{2}$ to the cave air, the escaping gas is enriched in ${ }^{12} \mathrm{C}$, which raises the $\delta^{13} \mathrm{C}$ in the remaining water and in subsequent carbonate deposits. In contrast, evaporation of cave water preferentially removes ${ }^{16} \mathrm{O}$, causing a negative $\delta^{18} \mathrm{O}$ shift in the vapor. This causes a positive $\delta^{18} \mathrm{O}$ shift in the remaining water and in evaporative carbonate deposits (i.e., a shift toward the right in Fig. 3). Sequences of carbonate deposits tend to show a sharp increase in $\delta^{18} \mathrm{O}$ as degassing takes place this trend can be seen down flanks of stalagmites and across floors to pools. Evaporation also has an effect - generally over longer time, with deposits away from pools and fringes of speleothems showing greater effect. The combined effect is a steep positive slope, 
gradually diminishing in slope. Speleothems deposited chiefly by evaporation show a rightward shift in Fig. 3 (toward increasing $\delta^{13} \mathrm{C}$ ) but with little or no increase in $\delta^{18} \mathrm{O}$ from degassing. See Lohmann (1988) for details.

When water vapor condenses on solid surfaces, it inherits some of the low $\delta^{18} \mathrm{O}$ of the water vapor. Also, the condensate absorbs $\mathrm{CO}_{2}$ from the cave air, acquiring $\delta^{13} \mathrm{C}$ that is much lighter than that of carbonate bedrock and most speleothems. Therefore, resulting corrosion residues show diminished $\delta^{18} \mathrm{O}$ and $\delta^{13} \mathrm{C}$ relative to the original carbonates. Condensation water can deposit carbonate minerals only by evaporation, since it is already at equilibrium with cave $\mathrm{CO}_{2}$. The initial deposits from this water are depleted in both $\delta^{18} \mathrm{O}$ and $\delta^{13} \mathrm{C}$ relative to speleothems deposited from meteoric water. Subsequent evaporative deposits continue to increase in $\delta^{18} \mathrm{O}$ but have rather steady $\delta^{13} \mathrm{C}$, causing a trend toward the right (c) in Fig. 3.

If the evaporated water condenses on cooler surfaces above, it absorbs $\mathrm{CO}_{2}$ from the cave air (low in $\delta^{13} \mathrm{C}$ ) and dissolves some of the carbonate substrate. This, in combination with the relatively low $\delta^{18} \mathrm{O}$ from the water, causes isotopes in the weathered carbonates to trend toward the lower left (e) in Fig. 3. Precipitates formed in drip-water from the condensate also show this trend.

Upwelling groundwater from hypogenic sources has apparently not been active for at least the past half million years. Isotopic values for mammillaries that were deposited soon after the last influx of $\mathrm{H}_{2} \mathrm{~S}-$ rich water show low $\delta^{13} \mathrm{C}$ values, but not significantly different from those of more recent deposits from condensation moisture in equilibrium with cave air.

\section{LATE-STAGE PROCESSES AND FEATURES IN GUADALUPE CAVES}

The following sections concern processes that have operated in the caves during and after the last major phase of sulfuric acid speleogenesis, over roughly the last $4 \mathrm{My}$. Features described here are most diagnostic of cave conditions. A few have not been described before. Those that are well known are mentioned only briefly, and many of secondary importance are omitted.

\section{Sulfuric Acid Dissolution}

Oxidation of $\mathrm{H}_{2} \mathrm{~S}$ to sulfuric acid takes place only in aqueous solution, so cave enlargement is limited to sulfide-bearing groundwater and streams in contact with an oxygen source, and to films and droplets of moisture that absorb $\mathrm{H}_{2} \mathrm{~S}$ and $\mathrm{O}_{2}$ from the cave air. Sulfuric acid is produced by the $\mathrm{H}_{2} \mathrm{~S}+2 \mathrm{O}_{2}$ reaction (usually with intermediate steps) and is accelerated by microbial processes (Engel, 2004). Acidic water in direct contact with carbonate rock is quickly buffered by release of bicarbonate ions, maintaining a $\mathrm{pH}$ of about 6.3-7.2, while a continued influx of $\mathrm{H}_{2} \mathrm{~S}$ and $\mathrm{O}_{2}$ is required to sustain the reactions. Passage widening in the Guadalupe caves tends to be greatest at former surfaces of streams or pools, but domed cross sections suggest that the greatest volume of carbonate dissolution was subaerial. In the Frasassi Cave System of Italy, an active analog of Carlsbad, Galdenzi et
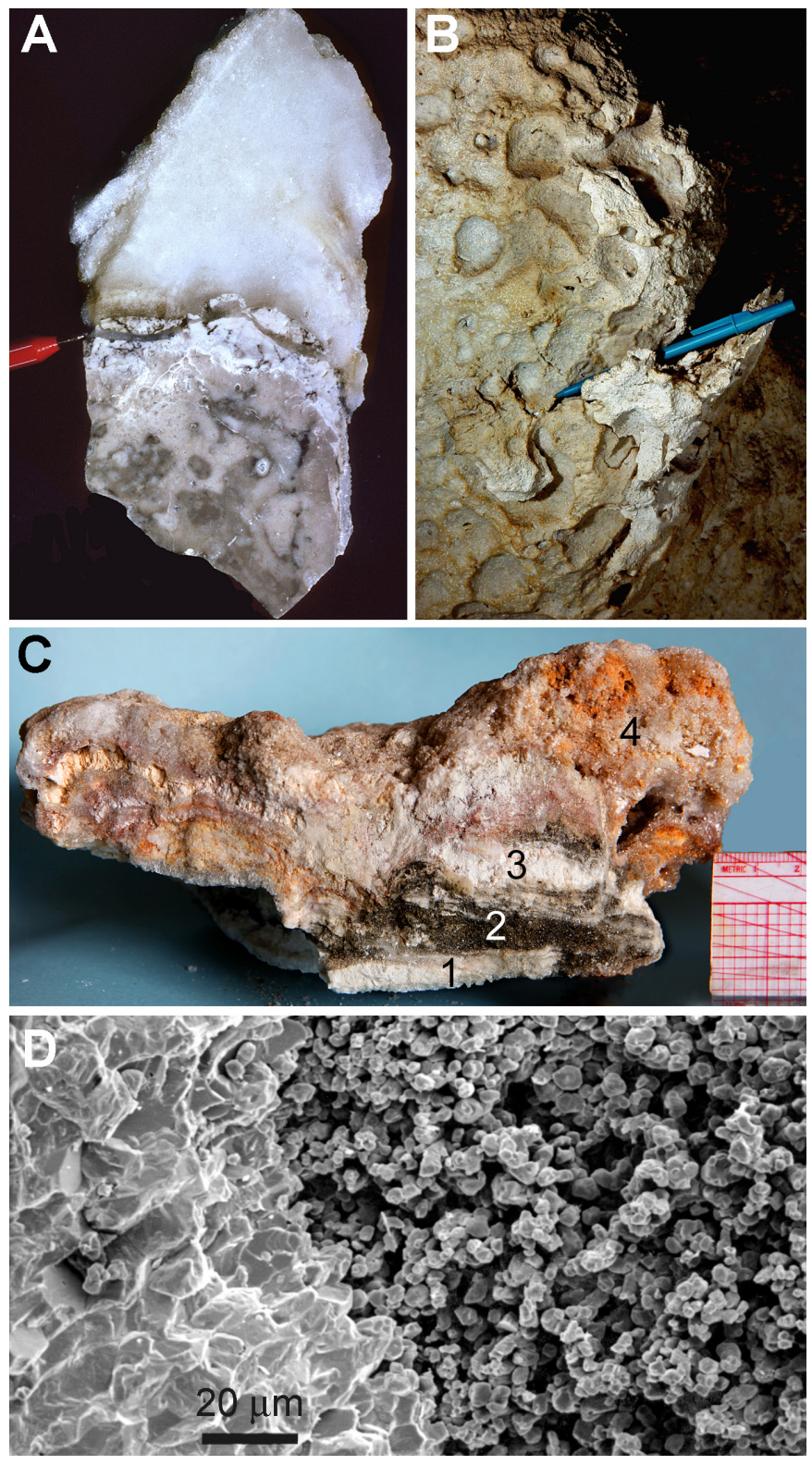

Fig. 4. Early micritized bedrock rinds. A) Secondary gypsum (top) with wedging and partial assimilation of bedrock, overlying white micritized and dolomitized bedrock rind, Lechuguilla Cave. B) White micritized crust on limestone, cut by solution pockets, Left Hand Tunnel, Carlsbad Cavern. C) White micritized, dolomitized bedrock rind in Lechuguilla Cave (1), overlain by residue from $\mathrm{H}_{2} \mathrm{SO}_{4}$ dissolution: $2=\mathrm{Mn}$ oxides; $3=$ alunite, $4=$ Al-rich clay and Fe oxides in gypsum. Upper scale in $\mathrm{cm}$ and $\mathrm{mm}$. D) Contact between unaltered limestone (left) and micritized calcite rind, Carlsbad. Note disaggregation and diminished crystal size in rind.

al. (1997) show that $\mathrm{H}_{2} \mathrm{SO}_{4}$ dissolution by condensation moisture on aerated surfaces is at least as rapid as in sulfide-rich streams and lakes below.

As carbonate rock dissolves, concentrations of $\mathrm{Ca}^{2+}$ from the rock and $\mathrm{SO}_{4}{ }^{2-}$ from the acid often increase enough to precipitate replacive ("speleogenetic") gypsum. Negative $\delta^{34} \mathrm{~S}$ values in the gypsum of Guadalupe caves suggests a biogenic $\mathrm{H}_{2} \mathrm{~S}$ source (Hill, 1987). Chemical modeling shows that gypsum replacement requires the consumption of $>0.014 \mathrm{~mol} \mathrm{~L}^{-1}$ of sulfuric acid by carbonate dissolution. This process is predominantly subaerial. For it to occur subaqueously the water must already be at or near gypsum 

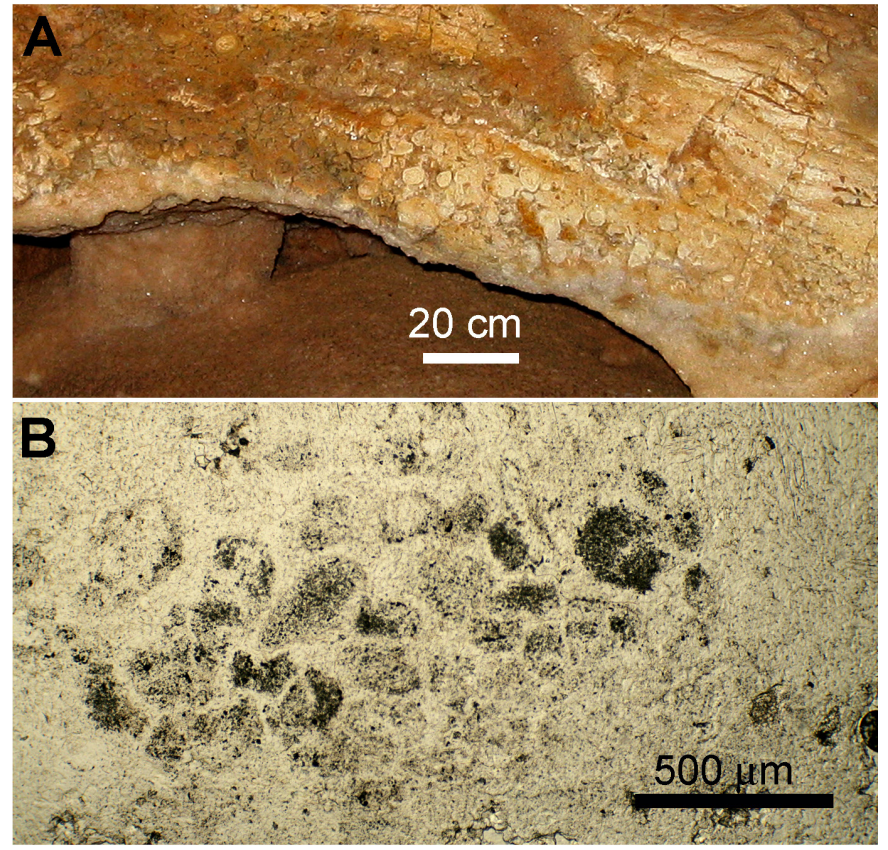

Fig. 5. Gypsum replacement textures. A) Ghosts of carbonate pisolites in backreef beds, converted to gypsum (Dry Cave, $15 \mathrm{~km}$ north of Carlsbad Cavern) Photo by Gosia Allison-Kosior. B) Relics of reef rock in gypsum are rare and are recognized by carbonate inclusions (shown), Fe oxides or differences in gypsum crystal size, PL. Notation for photomicrographs: $\mathrm{PL}=$ Plane-polarized light; $\mathbf{X P}=$ Cross-polarized light; $\mathbf{R L}=$ Reflected light; Red stain for calcite $=$ Alizarin Red S.

saturation. As gypsum crusts cover the bedrock, additional acid diffuses inward through the gypsum to sustain carbonate dissolution, while the crusts thicken. Crystallization of gypsum can force slivers of bedrock and insoluble residue from the wall, leaving them "floating" in the crust (i.e., with no contact between fragments, Fig. 4A). Gypsum blocks occasionally fall to the floor, exposing corroded bedrock. The blocks can coalesce into moist glacier-like masses in which the outlines of bedrock fragments are identifiable only by a difference in gypsum crystal size, or by scattered $\mu \mathrm{m}$-size inclusions of carbonate or $\mathrm{Fe}$ oxide (Fig. 5).

The contact between bedrock and replacive gypsum contains rounded hollows, typically about 5-10 $\mathrm{cm}$ in diameter, where dissolution has been most intense (Fig. 4B). In the actively dissolving walls of Villa Luz these hollows are lined by anhydrite needles (Fig. 6). Anhydrite becomes sparse outward from the bedrock contact and apparently alters to gypsum with time. Anhydrite normally requires temperatures above $65{ }^{\circ} \mathrm{C}$ or humidity below $~ 75 \%$ (Hardie, 1967), neither of which is present in Villa Luz. Instead, carbonate dissolution must sometimes be rapid enough to bring both anhydrite and gypsum to supersaturation, allowing them to co-precipitate. We have not yet found anhydrite or its pseudomorphs along former reaction fronts in the Guadalupes, but some floor deposits contain residual anhydrite crystals (see Basin Sediments).

Replacive gypsum can preserve bedrock textures and grain shapes (Figs. 5 \& 7). Rapid $\mathrm{H}_{2} \mathrm{SO}_{4}$ dissolution of carbonate releases $\mathrm{CO}_{2}$ gas, and the increased

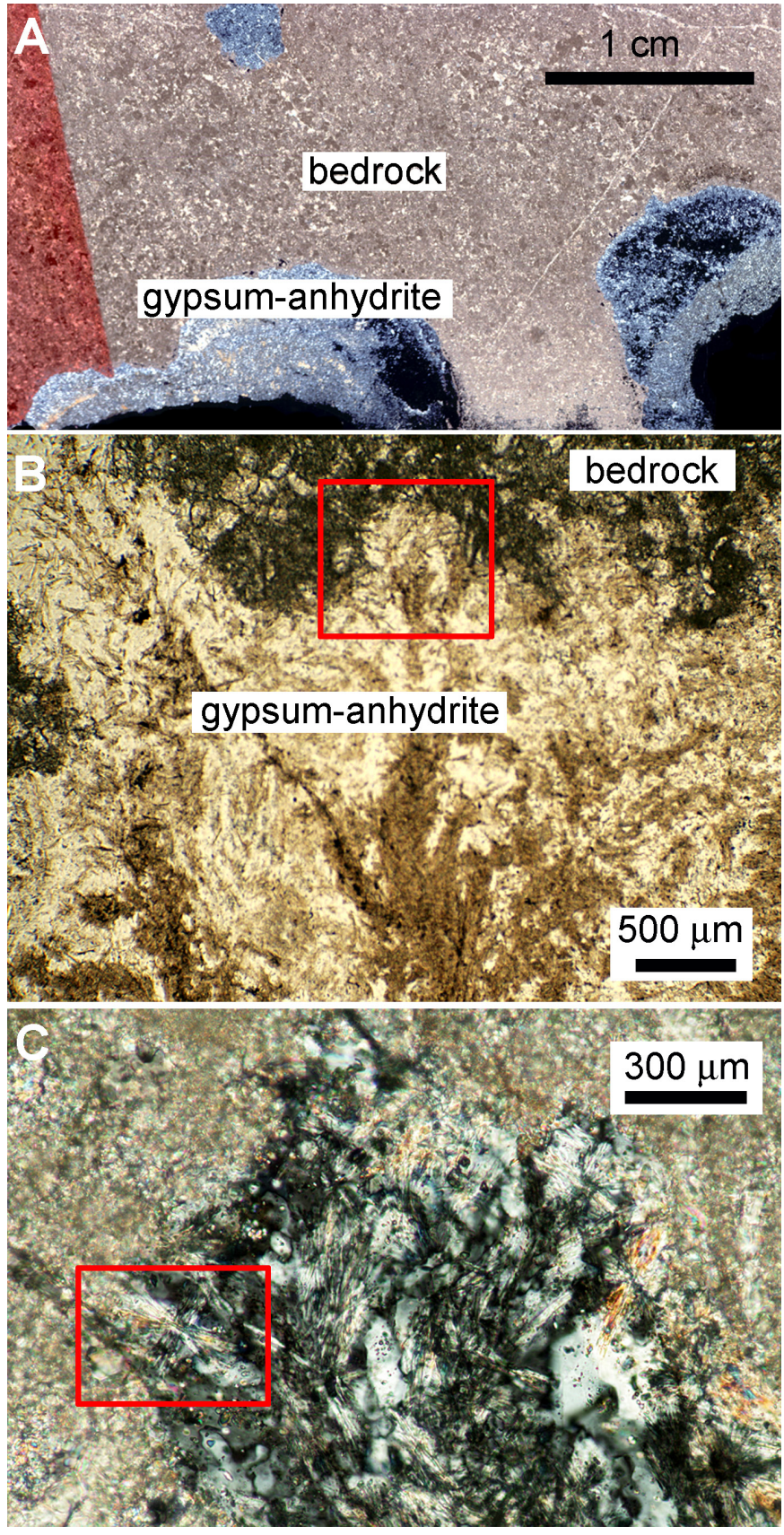

Fig. 6. Anhydrite in solution pockets, Villa Luz: A) Felted anhydrite (lighter) and gypsum in enlarging $\mathrm{H}_{2} \mathrm{SO}_{4}$ solution pockets. Red stain for calcite, XP. B) Anhydrite needles with major growth perpendicular to bedrock contact, PL. C) Enlarged view of box in $\mathrm{B}, \mathrm{XP}$; anhydrite needles = bright. Box shows anhydrite rosettes.

$\mathrm{PCO}_{2}$ in the cave can enhance bedrock dissolution. In a closed system, with no $\mathrm{CO}_{2}$ loss, approximately two moles of calcite are consumed for each mole of gypsum deposited, and because the molar volume of gypsum is almost exactly twice that of calcite (within 1\%), a 1:1 volume ratio of gypsum to calcite is preserved. In well-aerated caves, however, much of the generated $\mathrm{CO}_{2}$ is lost, and the solutional capacity of the water is diminished (Palmer, 1991). If so, the speleogenetic gypsum occupies more volume than the original bedrock and the original textures are disrupted. Gypsum replacement of dolomite in a closed system yields a volume increase of only $\sim 15 \%$, and some original bedrock textures can be preserved. 


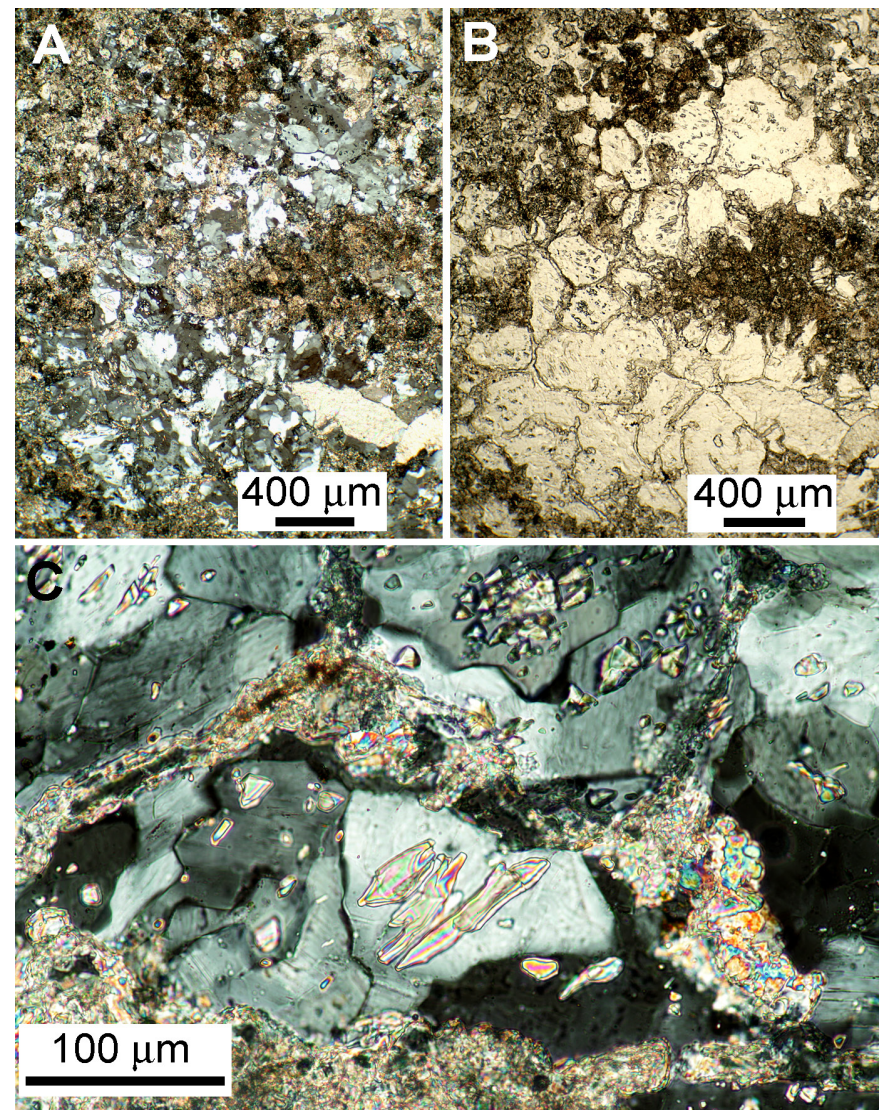

Fig. 7. Fabric-selective $\mathrm{H}_{2} \mathrm{SO}_{4}$ dissolution of limestone, Lechuguilla Cave. A) Replacive gypsum = gray, calcite = light sparkly tan, XP. B) Molds of former calcite are visible in PL. C) Slivers of corroded calcite floating in a gypsum-filled mold, XP.

$\mathrm{H}_{2} \mathrm{SO}_{4}$ alteration of clay typically produces alunite, hydrated halloysite, gibbsite, Fe-Mn oxides and hydroxides (hereafter simplified to "oxides") and opal (Polyak \& Güven, 2000; Fig. 4C). All can occur as inclusions in replacive gypsum or as residuum on weathered bedrock. Fe and $\mathrm{Mn}$ are most soluble at low $\mathrm{pH}$ and/or Eh and tend to precipitate when either variable increases. Stability fields for oxidized Fe minerals extend to lower $\mathrm{pH}$ and Eh than those of $\mathrm{Mn}$, so the two are often segregated. Fe oxides are scattered throughout the replacive gypsum, while Mn oxides tend to concentrate along the carbonate contact where acidity is less intense (Fig. 8). As the gypsum thickens, oxides and clay residue are concentrated as irregular strands coated with opal (Fig. 9). Spilde et al. (2005) demonstrate microbial enhancement of Fe-Mn corrosion in the Guadalupe caves (cf. Fig. 10). Replacive gypsum in Villa Luz contains a ubiquitous, viscous red-brown biofilm. There are no obvious traces in the Guadalupes, although phosphate is present in scattered crandallite $\left[\mathrm{CaAl}_{3}\left(\mathrm{PO}_{4}\right)\left(\mathrm{PO}_{3} \mathrm{OH}\right)(\mathrm{OH})_{6}\right]$ and fluorapatite $\left[\mathrm{Ca}_{5}\left(\mathrm{PO}_{4}\right)_{3} \mathrm{~F}\right]$, which accompany Fe-Mn oxides and other alteration products of sulfuric acid at the bedrock contact (Fig. 10C). Phosphorus is removed from organic debris at low $\mathrm{pH}$ or $\mathrm{Eh}$, and forms phosphates at alkaline pH (Blatt et al., 1980).

Deposits of elemental sulfur occur in many Guadalupe caves as the result of incomplete oxidation of $\mathrm{H}_{2} \mathrm{~S}$. Sulfur is most stable at low $\mathrm{pH}$, so it is generally distributed on or within non-carbonate materials that do not neutralize the acidity.
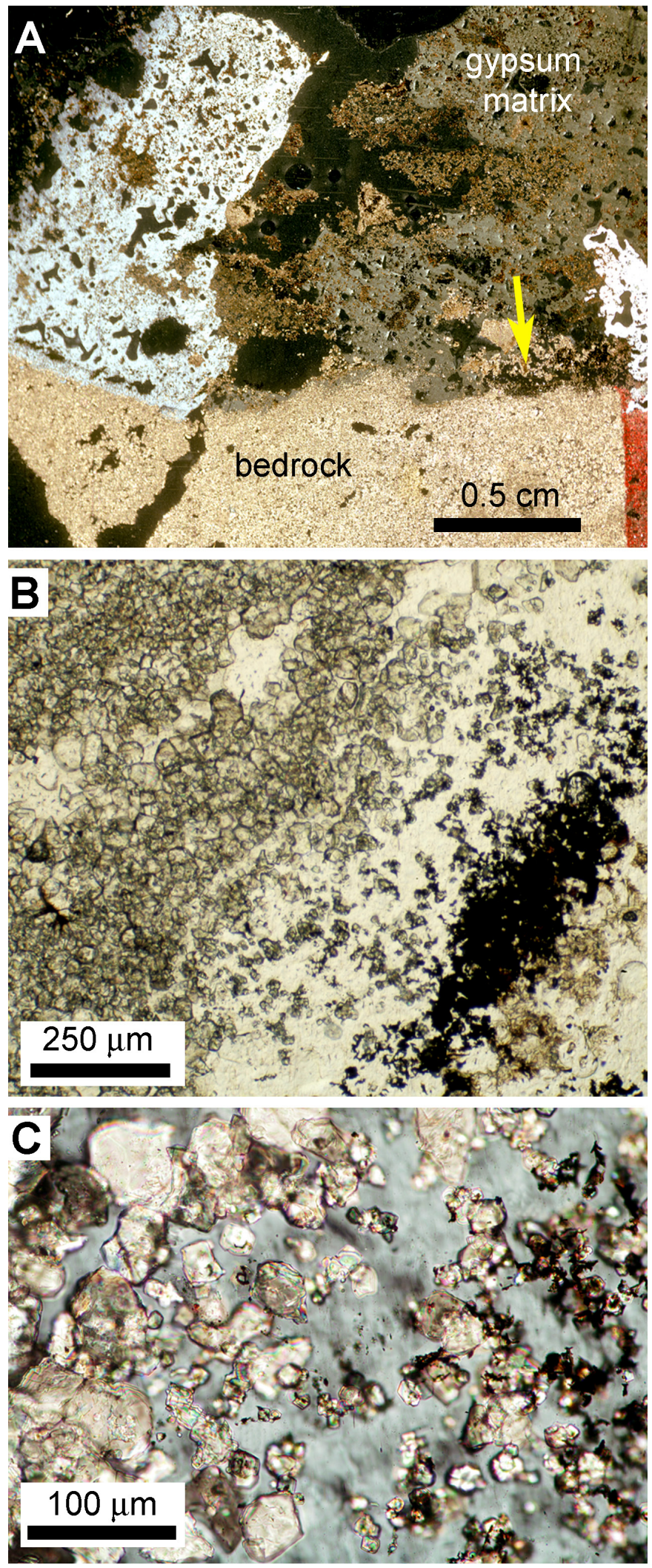

Fig. 8. Bedrock-gypsum reaction front, Spider Cave. A) Gypsum containing corroded bedrock, clay, and alteration products, including Fe-Mn oxides. Arrow = location of B \& C; XP, red stain for calcite. B) Detached crystals become increasingly corroded. $\mathrm{Mn}$ oxides (black) are concentrated at and near the bedrock contact. PL. C) Enlarged view of B. Decrease in crystal size is due to surface corrosion, not growth of internal pores. Fe$\mathrm{Mn}$ oxides are attached to partially dissolved calcite crystals. Gypsum = gray; XP. 

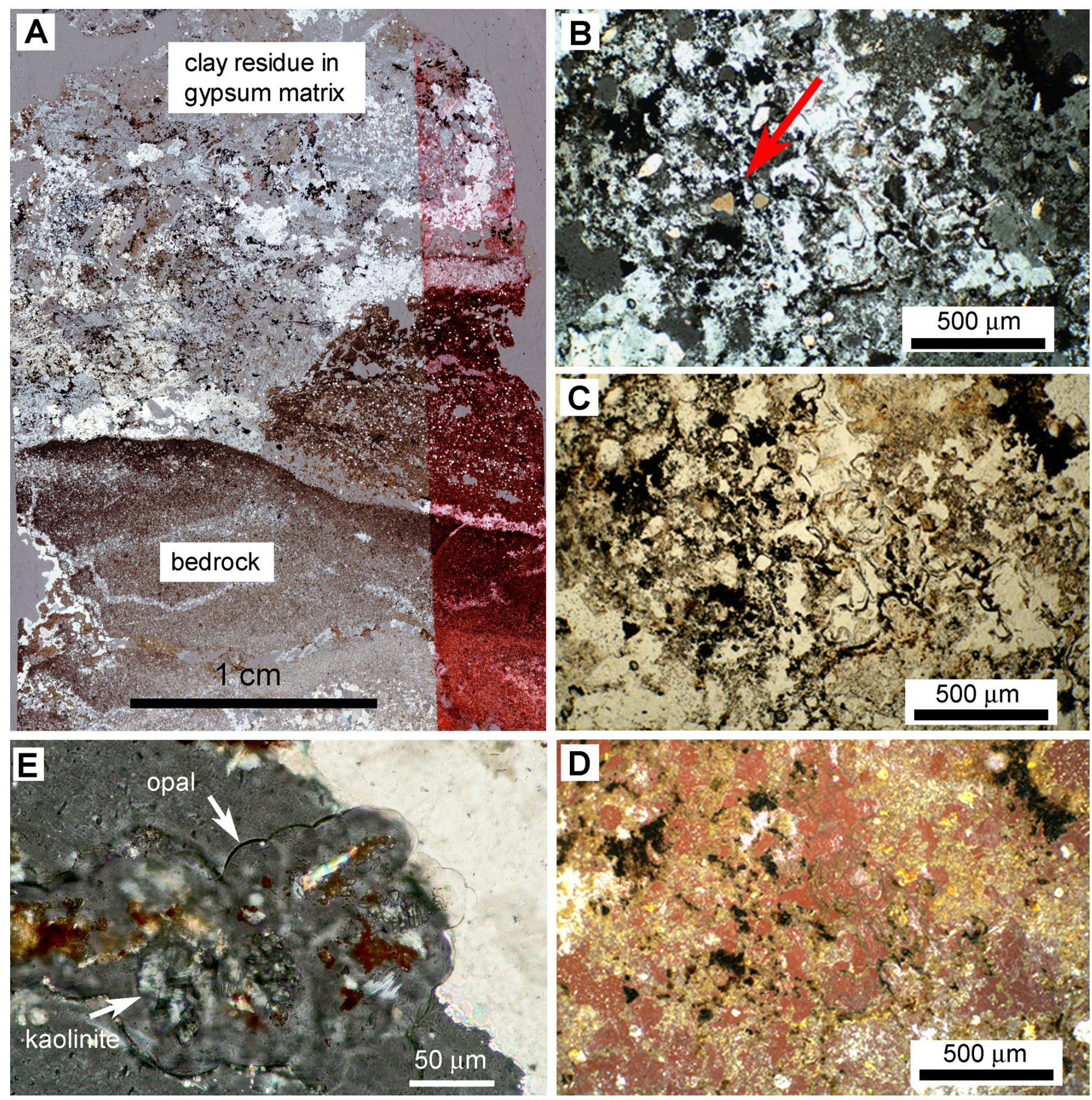

Fig. 9. Fe-Mn strands formed during growth of replacive gypsum. A) Clay residue floating in replacive gypsum at contact with limestone, Lechuguilla Cave. Red stain for calcite, XP. B) Fe-Mn oxides, quartz silt (arrow), and clay residue in gypsum matrix (gray), XP. C) Fe-Mn oxide strands (black), same as B but PL. D) Same as B and C, but RL. Mn oxides = black, Fe oxides = yellow, clay inclusions = white. E) Enlarged view of Fe-Mn strand, with opal rind surrounding Fe-Mn oxides and clay residue, XP. B-E from Spider Cave.

\section{Micritic Rinds}

Some dissolutional bedrock surfaces have been micritized (crystal size diminished to microscopic scale) to form coherent white rinds up to about 1 $\mathrm{cm}$ thick (Fig. 4). Many rinds have been intersected or removed by later dissolution, or are covered with gypsum and are disturbed by gypsum wedging. Where rinds intersect fossils in bedrock, the fossil outlines are still visible (Fig. 11). Thin micrite rinds are also present in Villa Luz at the gypsum-limestone contact where $\mathrm{H}_{2} \mathrm{SO}_{4}$ dissolution is active today (Fig. 12). Presumably that also once applied to the Guadalupe caves.
Micritic rinds on limestone show negative shifts in both $\delta^{13} \mathrm{C}$ and $\delta^{18} \mathrm{O}$ relative to the host rock (Fig. 3). The $\delta^{18} \mathrm{O}$ shift shows interaction of bedrock with meteoric water, and the $\delta^{13} \mathrm{C}$ shift shows the influence of cave-air $\mathrm{CO}_{2}$. The changes are small because dissolution and reprecipitation were limited to thin zones along grain boundaries, while most of the original rock was unaffected (Fig. 11). Micritization by sulfuric acid alone should ideally produce no shift in $\delta^{13} \mathrm{C}$, because $\mathrm{H}_{2} \mathrm{SO}_{4}$ does not contain carbon, and any $\mathrm{CO}_{2}$ released by the reaction is derived from the limestone itself. Therefore the negative shift in $\delta^{13} \mathrm{C}$ shows some involvement with $\mathrm{CO}_{2}$ in the cave air. 

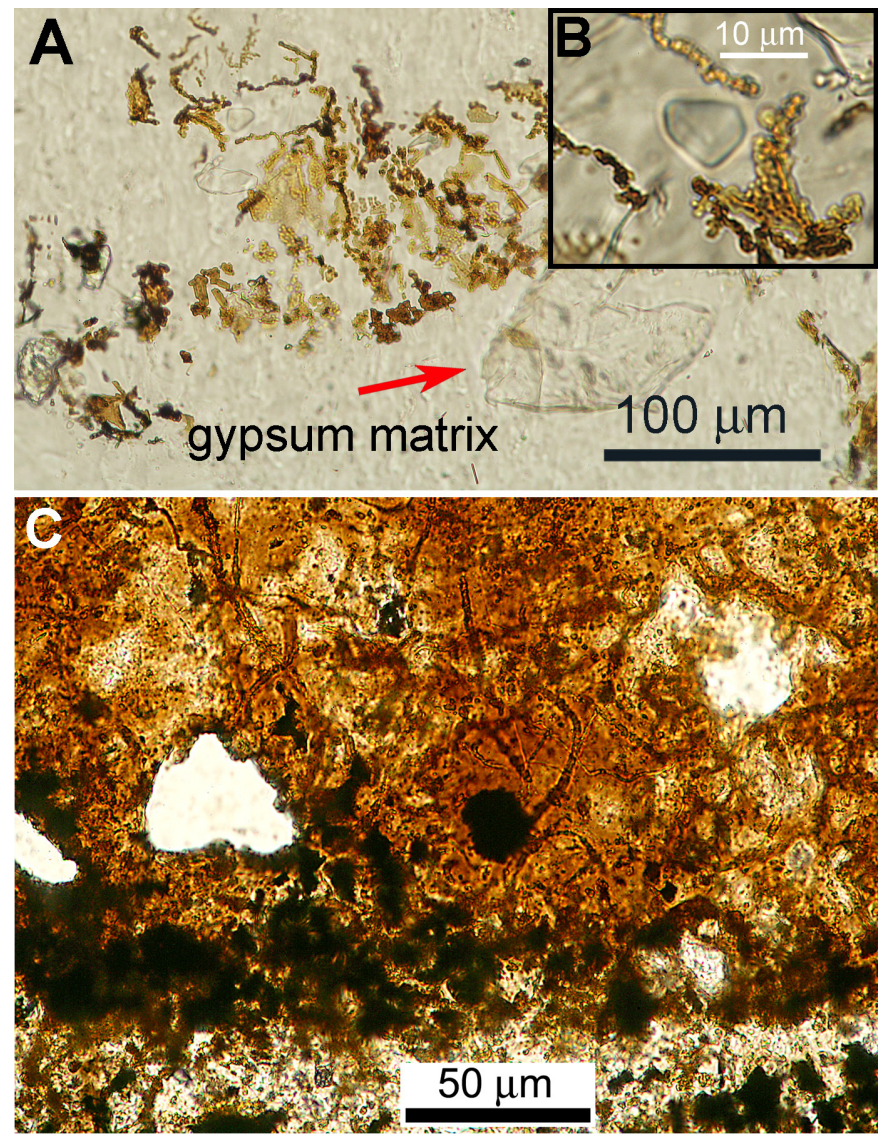

Fig. 10. Microbial textures in Fe-Mn oxides, Lechuguilla Cave. A) Oxide strands in replacive gypsum (arrow $=$ corroded calcite), PL. B) Enlarged view shows apparent cell structures. C) Filaments coated with Fe-Mn oxides in a crandallite matrix, with clay-rich corrosion residue from back-reef beds, PL.

Insight is provided by epigenetic Mammoth Cave, Kentucky, where release of sulfuric acid by oxidation of pyrite in limestone has produced bleached micritic haloes. The haloes show an isotopic shift of $-1.7 \%$ in $\delta^{18} \mathrm{O}$ from unaltered bedrock, but only $-0.7 \%$ in $\delta^{13} \mathrm{C}$ (Fig. 3, CW347br-CW347c). The $\delta^{18} \mathrm{O}$ shift is caused by interaction with capillary water, and the $\delta^{13} \mathrm{C}$ shift
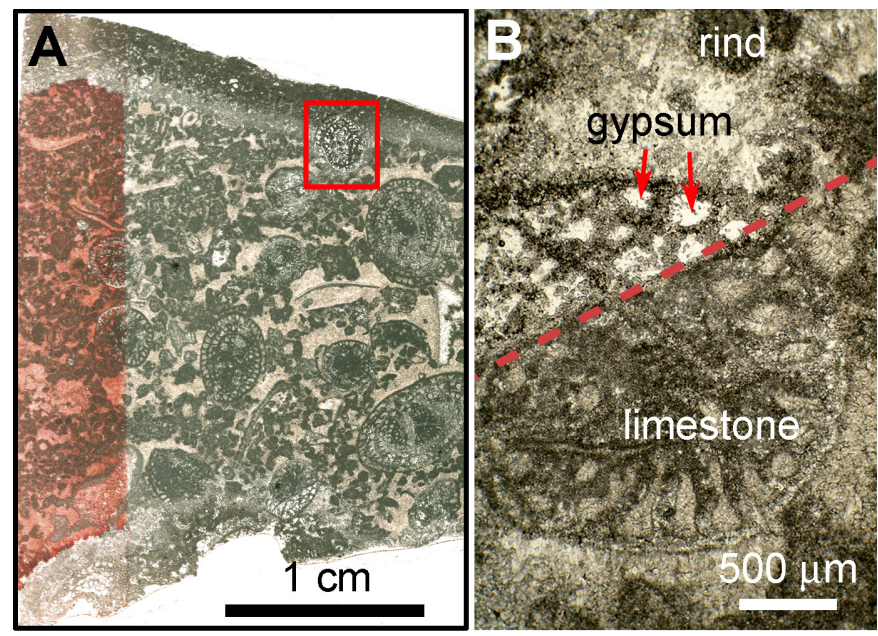

Fig. 11. Detail of $\mathrm{H}_{2} \mathrm{SO}_{4}$-micritized rind. A) Dolomitized micritic rind, Lechuguilla Cave, PL, red stain for calcite. B) Enlarged view of box in A: Corroded, dolomitized bedrock (above dashed line), PL. Fossil in rind shows that the rind was originally bedrock.

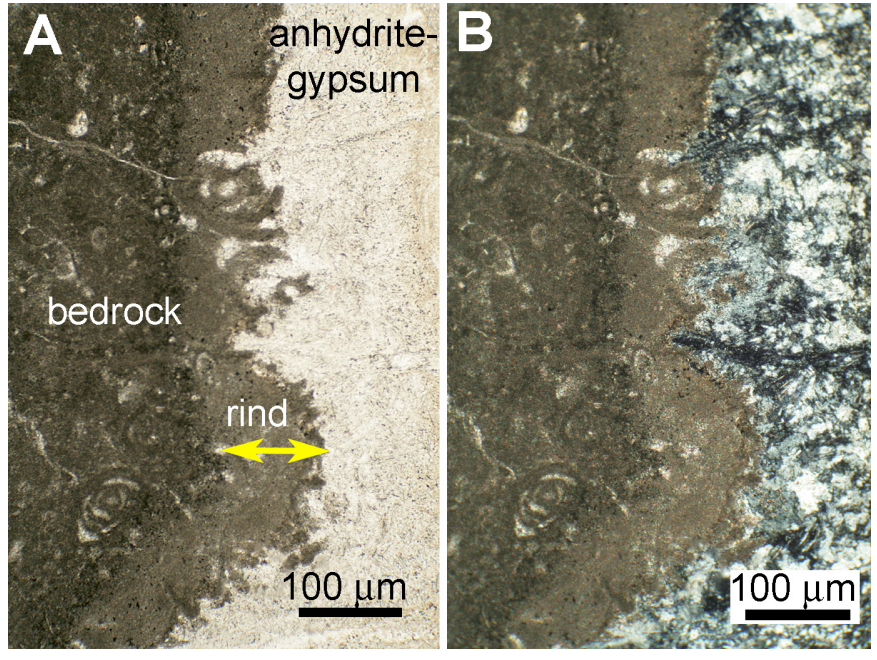

Fig. 12. Cueva de Villa Luz, Mexico: active micritization of bedrock (note fossils). Rind forms subaerially near an $\mathrm{H}_{2} \mathrm{~S}$ inlet and appears to be contemporary with replacive anhydrite-gypsum. $A=P L$. $\mathrm{B}=\mathrm{XP}$

shows interaction with $\mathrm{CO}_{2}$ absorbed from the cave air. Elsewhere in the cave, white micritized rinds up to $3 \mathrm{~cm}$ thick are produced on limestone where $\mathrm{CO}_{2}$ depleted water seeps into the cave and absorbs $\mathrm{CO}_{2}$ from the cave air (Fig. 13; Palmer, 2007, p. 345). Both $\delta^{18} \mathrm{O}$ and $\delta^{13} \mathrm{C}$ are offset about $-1 \%$ from the unaltered rock (Fig. 3, CW15br-CW15b). The isotopic shifts in these presently active examples resemble those in the apparently relict examples of the Guadalupe caves.

\section{Dolomitization}

Some of the micrite rinds are composed of dolomite. This is ordinarily not a common cave mineral but is widespread in Guadalupe caves, where it also forms many late-stage speleothems. Dolomite precipitation or replacement requires high $\mathrm{Mg} / \mathrm{Ca}$ and $\mathrm{CO}_{3}{ }^{2-}$ (thus high $\mathrm{pH}$ ), and is favored by evaporation, high temperature, sulfate reduction, and much time. Thrailkill (1968) showed that the chemistry of water films on and near dolomite speleothems lies within the range of dolomite stability; and Polyak (1992) noted conversion of calcite to Mg-rich speleothems, including well-ordered dolomite. The main source of $\mathrm{Mg}$ in Guadalupe caves is dolomite bedrock. Dolomite

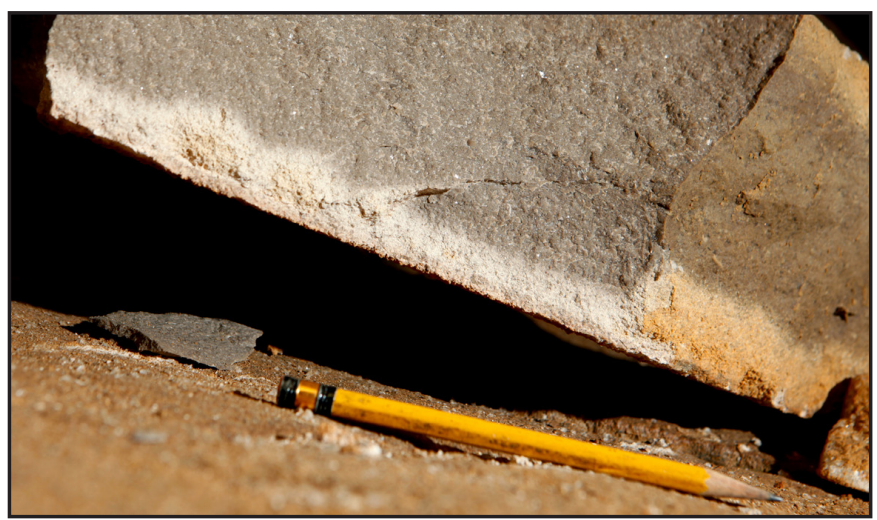

Fig. 13. Micritized limestone rind, Mammoth Cave, Ky., where low$\mathrm{CO}_{2}$ seepage has absorbed $\mathrm{CO}_{2}$ from cave air. Despite different origin, isotopic shifts resemble those of Guadalupe rinds. 


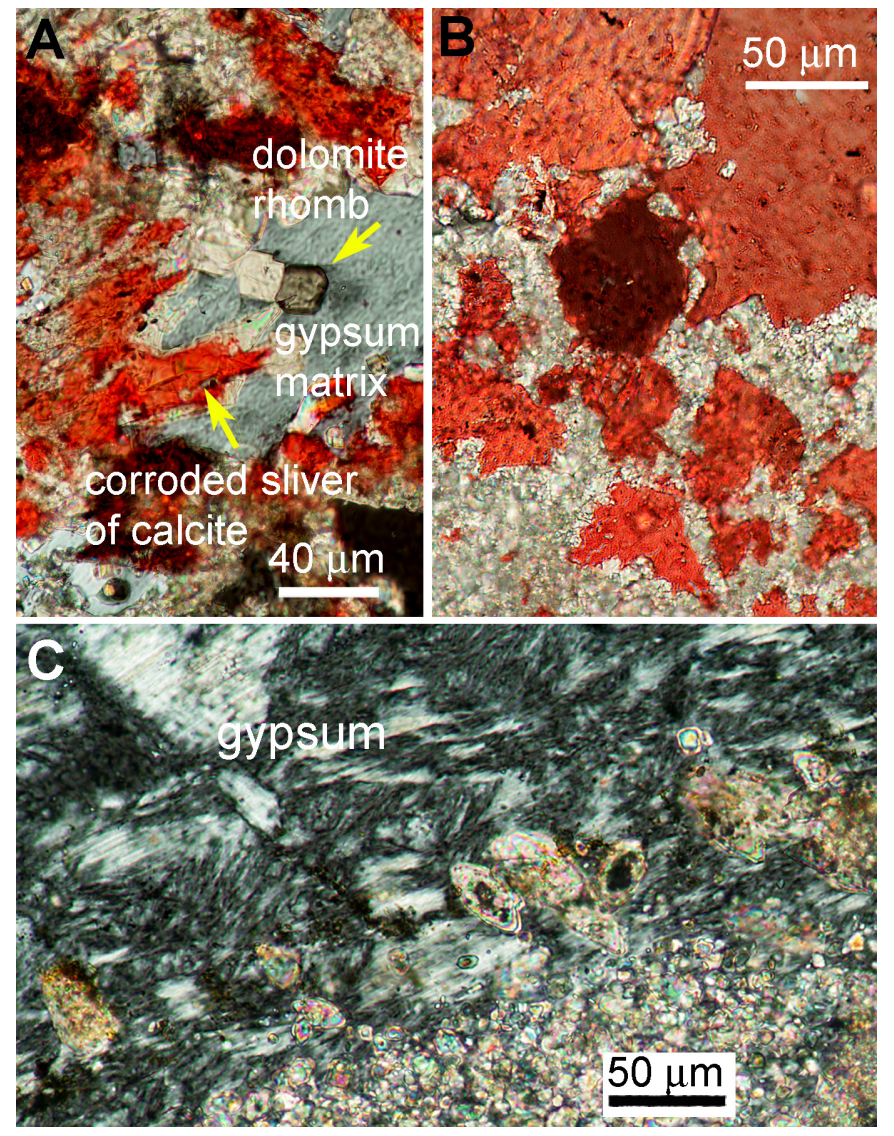

Fig. 14. Primary dolomite at $\mathrm{H}_{2} \mathrm{SO}_{4}$ solution front, Lechuguilla Cave. A) Dolomite rhomb at limestone-gypsum contact, $\mathrm{XP}$, red stain for calcite. B) Primary dolomite rind in $\mathrm{H}_{2} \mathrm{SO}_{4}$ basin invading limestone along calcite cleavage, XP. Isotopes distinguish between primary and replacive dolomite (see text and Fig. 3, LG805c). C) Lenticular dolomite crystals nucleated on micritic rind, XP.

has been synthesized at $>55{ }^{\circ} \mathrm{C}$ (Mandrikova et al., 1975), but this is well above the temperature of the present caves. Microbial sulfate reduction can catalyze dolomite precipitation (Wright \& Wacey, 2004) but this requires anoxic conditions, which were uncommon in the late-stage cave environment. Thus evaporation and abundant time are the likely agents for most dolomite deposition in the Guadalupes.

If dolomite rinds form on limestone by simple replacement of $\mathrm{Ca}$ by $\mathrm{Mg}$ [i.e. $2 \mathrm{CaCO}_{3}+\mathrm{Mg}^{2+} \rightarrow$ $\left.\mathrm{CaMg}\left(\mathrm{CO}_{3}\right)_{2}+\mathrm{Ca}^{2+}\right]$, no carbonate exchange is involved and there is ideally no isotopic shift. Intact fossil outlines in dolomite rinds support this process (Fig. 11). These rinds show a small negative shift in $\delta^{13} \mathrm{C}$ from limestone, as in calcite rinds, but less so in $\delta^{18} \mathrm{O}$ (Fig. 3, LG 212 \& LG819). Differences in fractionation between calcite and dolomite may account for the smaller $\delta^{18} \mathrm{O}$ shift.

Some dolomite rinds have formed instead by direct precipitation (Fig. 3, LG805br-LG805c; Fig. 14) and show a large contrast in $\delta^{13} \mathrm{C}$ from the bedrock. Most contain varied morphologies as the result of changing chemical environments (Fig. 15). Some micrite rinds beneath speleogenetic gypsum are coated with younger, $\sim 50 \mu \mathrm{m}$ lenticular dolomite crystals with micritic cores (Fig. 14C). These probably formed by evaporitic wicking of moisture toward the aerated cave.

\section{Rills and Solution Basins}

Sulfuric acid can become very intense in contact with insoluble material. In Villa Luz, measured $\mathrm{pH}$ on bacterial filaments and gypsum extends down to zero. Like a sponge, gypsum can retain moisture, which continues to absorb $\mathrm{H}_{2} \mathrm{~S}$ and $\mathrm{O}_{2}$ to become strongly acidic. Where the acid drips from the gypsum, narrow rills are corroded in the underlying carbonate rock, with intervening sharp spires (Fig. 16). On gentler slopes, acidic flows can produce channels up to $\sim 15$ $\mathrm{cm}$ wide, which resemble surface karren. These involve only thin films of highly aggressive water spread over a wide area, or draining along gypsum-bedrock contacts. Gentle slopes also acquire solution basins (Fig. 17), which are roughly circular, typically 15-30 $\mathrm{cm}$ in diameter, and up to $15 \mathrm{~cm}$ deep. Some form clusters with spillover channels between them. Where gypsum has been dissolved away by later meteoric water, the origin of these rills and basins may seem puzzling. Rills formed by sulfuric acid generally underlie bedrock surfaces that show no sources of meteoric water inputs. In many places the rills are overlain by smooth and nearly flat ceilings. Except at and near the land surface, carbonate rocks in the Guadalupes show no rills clearly attributed to meteoric water flow.

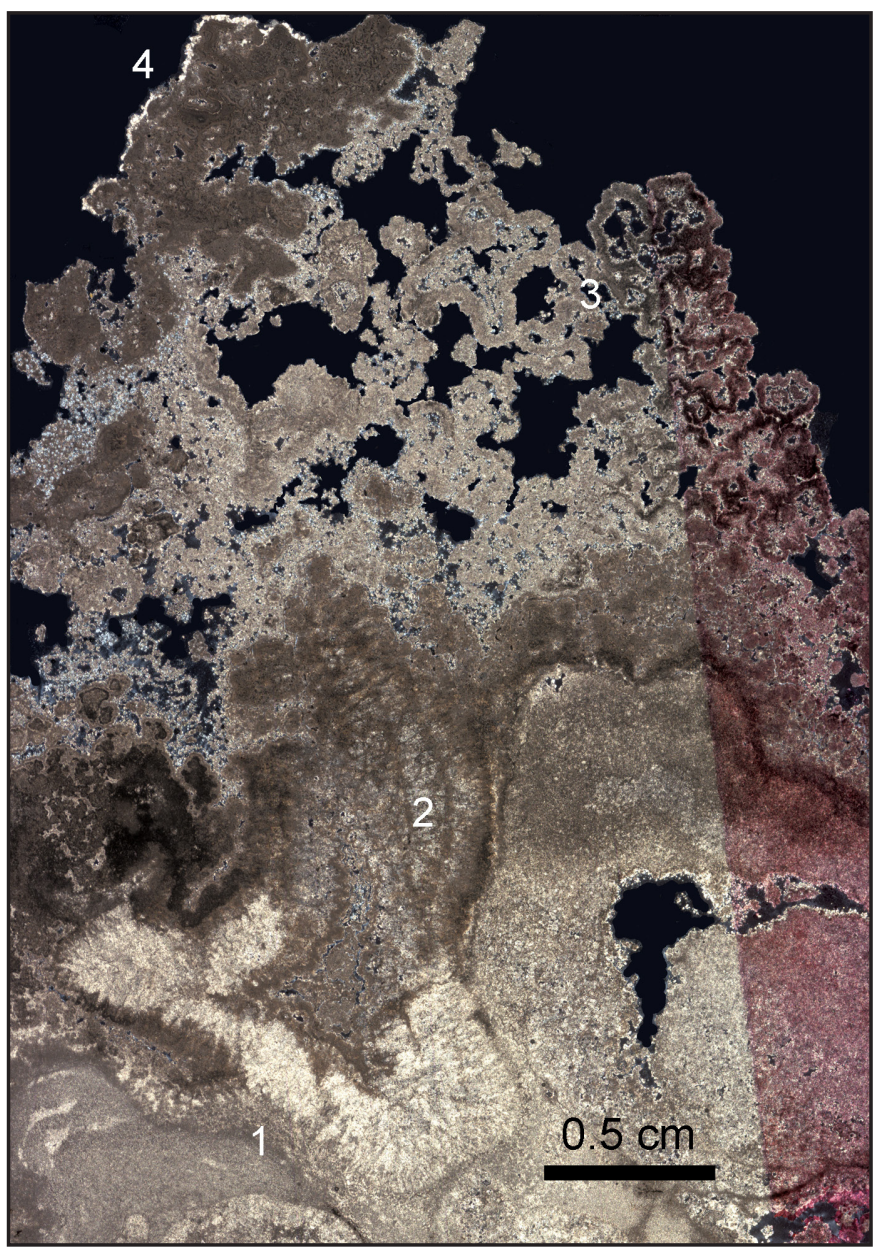

Fig. 15. Late precipitates impregnating early micritic rind, Lechuguilla Cave, XP, red stain for calcite. 1 = bedrock; 2 = micritic $\mathrm{H}_{2} \mathrm{SO}_{4}$ rind. Distortion shows that micrite was once moist and plastic. $3=$ evaporative dolomite replacement of convoluted hydromagnesite layers lined with chalcedony balls. $4=$ blocky calcite that grew beneath gypsum crust. Pores in crust are from gypsum dissolution. 

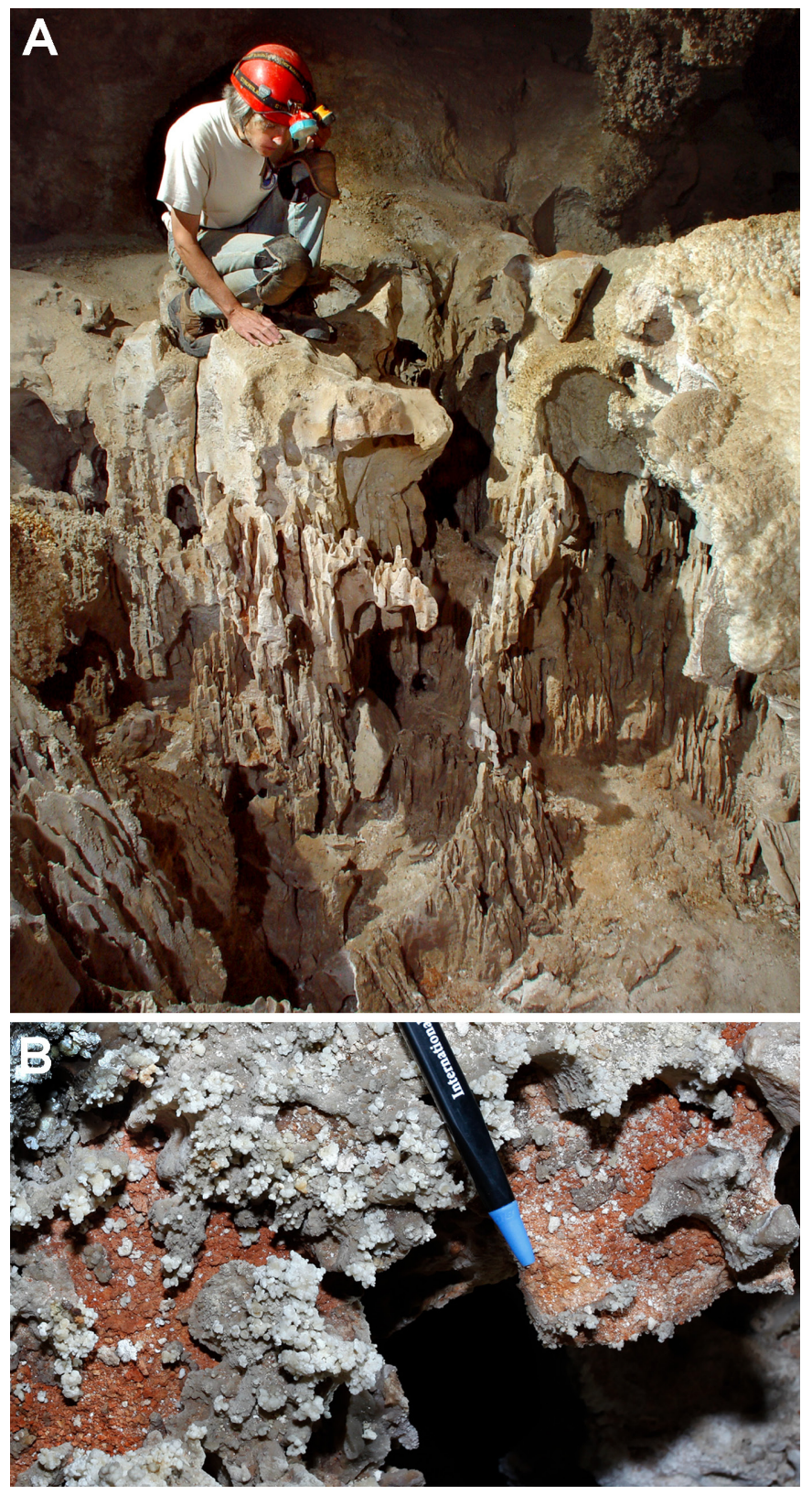

Fig. 16. Near the Left Hand Tunnel, Carlsbad Cavern. A) Solution rills in limestone formed by acid drainage from gypsum. Note remnant gypsum on ledge. B) Fe-rich bedrock residuum at base of rills.

\section{Basin Sediments}

Sediments in solution basins provide a record of post-solutional conditions. Three basins over a vertical range of $6 \mathrm{~m}$ were examined in the Near East of Lechuguilla Cave at $1050-1060 \mathrm{~m}$ asl (Figs. $2 \& 18$ ). They lie deep in the cave with no interference from vadose recharge. Natural breakdown allowed minimally invasive sampling of their contents.

In the two lower basins (Fig. 18, basins $2 \& 3$ ), the bedrock floor has a dolomitic rind (A2) that is absent in the upper basin. In the lowest basin (3) all sediments are also dolomitized. This irregular distribution may indicate local sulfate reduction with microbially derived carbon as the reducing agent. In all basins the oldest sediment (B) consists of quartz silt (probably residuum from bedrock dissolution) and detrital carbonate. In Basin 2, bed B includes fragments of anhydrite and gypsum, artifacts of sulfuric acid speleogenesis. By that time, local sulfuric acid processes had apparently ceased.

Bed C consists of detrital limestone grains and fossils cemented by calcite, but free of quartz silt (Fig. 19). It is probably corrosion residue from high above, because nearby bedrock contains no such fossils. Dissolution along crystal interfaces reveals delicate fabrics, a typical product of condensation water, rather than sulfuric acid. $\delta^{13} \mathrm{C}$ of dolomite in bed $\mathrm{C}$ (Fig. 3, LG805b) resembles that of evaporative speleothems. Carbonate debris has been micritized and impregnated by $1 \mu \mathrm{m}$ Fe oxide crystals forming a mottled pattern, possibly microbial (Riding, 2000), which nearly obliterate the original textures. Mottled portions are cemented by calcite extending downward from the overlying mammillary crust. As in bed B, preservation of delicate shells suggests slightly alkaline water.

A mammillary crust (D) consists of calcite interbedded with Fe-Mn-rich laminae that suggest periodic influxes of anoxic water. Abruptly overlying $\mathrm{D}$ is a 5 $\mathrm{mm}$ very finely crystalline, dark brown-black bed (E) with few fossils and cut by desiccation cracks. EDS analysis shows $\mathrm{Mn}>\mathrm{Fe}$. Bed $\mathrm{E}$ is absent in the lowest basin. In Basin 2, bed E terminates upward in laminated domal Mn-rich structures (Fig. 20A). It is common for Fe oxides to precede Mn oxides (see Sulfuric Acid Dissolution, and example in Luiszer, 2009). Bed
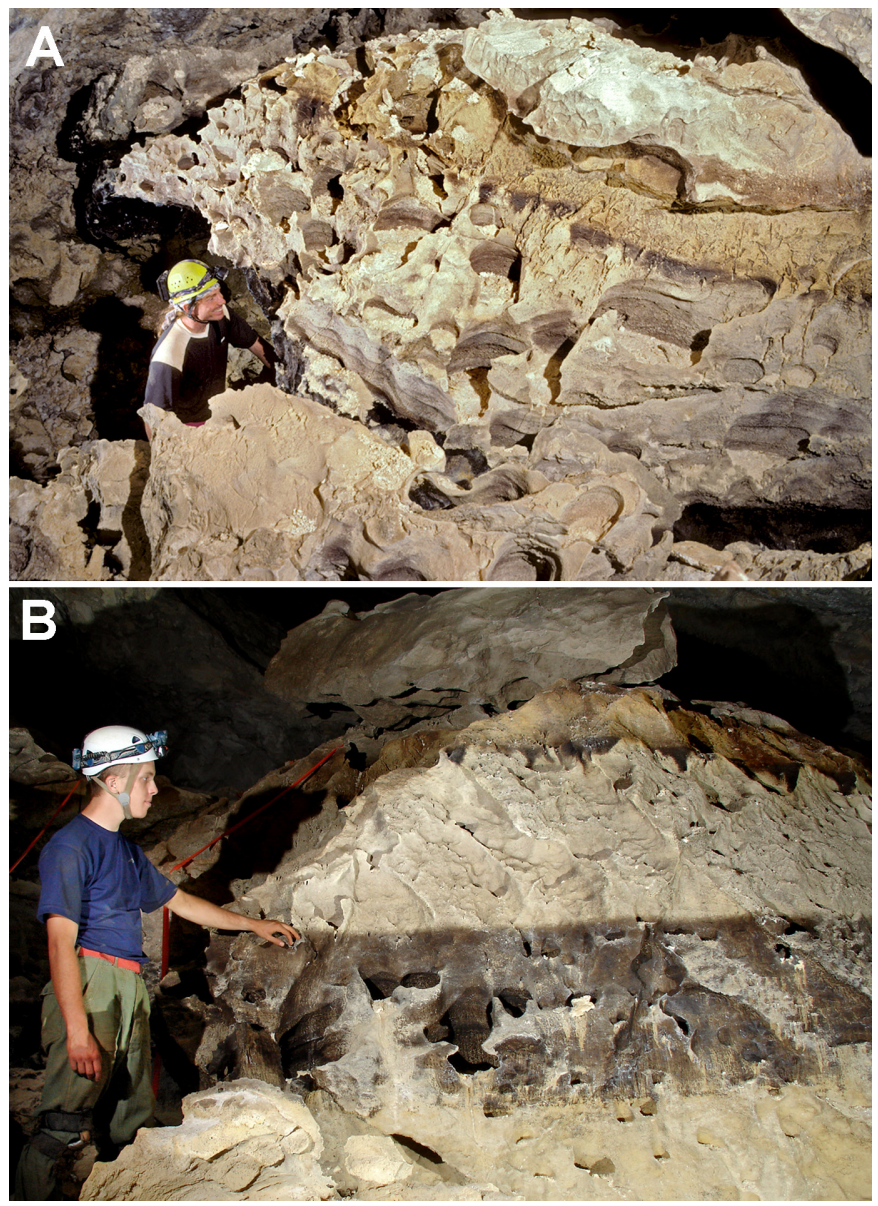

Fig. 17. Sulfuric acid solution basins in Near East, Lechuguilla Cave. A) Basins with rill infeeders, formed by acid drainage from former gypsum. B) Nearby water-level stains from a post-basin rise in water table; photo by Mark Tracy. 


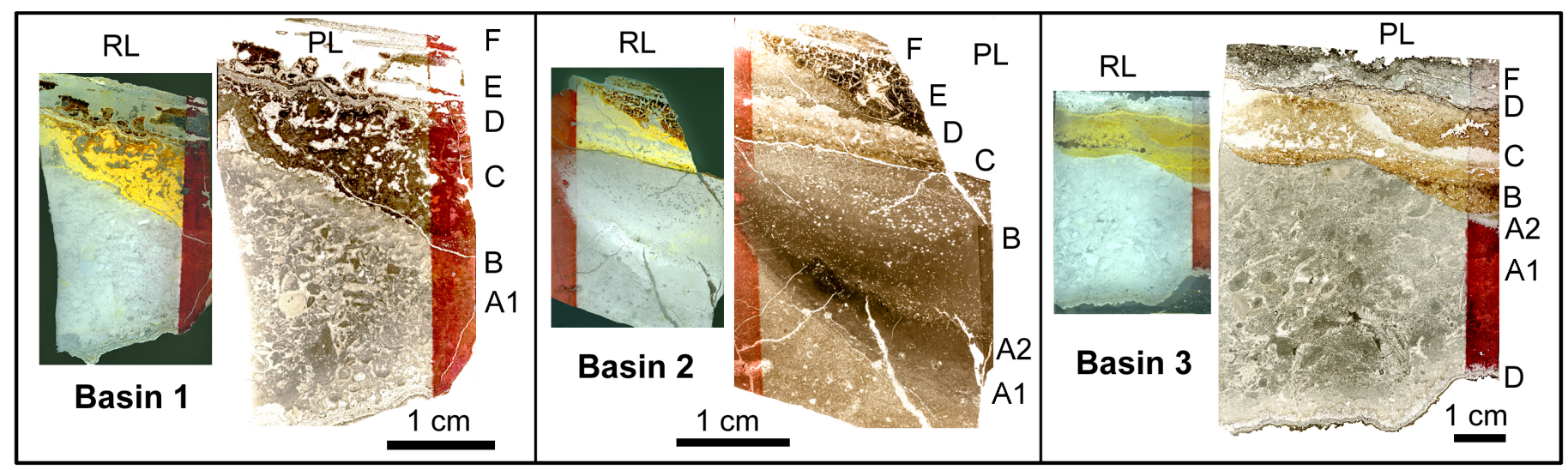

Fig. 18. Thin-section profiles of sediment in solution basins, Near East, Lechuguilla Cave, over a $6 \mathrm{~m}$ vertical range: 1, 2, 3 $=$ highest to lowest. Red dye for calcite. $\mathrm{A} 1$ = limestone bedrock. $\mathrm{A} 2=$ dolomitized micritic crust. $\mathrm{B}=$ bedrock residue from $\mathrm{H}_{2} \mathrm{SO}_{4}$ corrosion (quartz silt, detrital carbonate, anhydrite laths). $\mathrm{C}=$ yellow, Fe-oxide-rich corroded bedrock from cave ceiling, dolomitized in Basin 3. D = mammillary crust, dolomitized in Basin 3. E = black, mainly Mn-oxide-rich, desiccation-cracked carbonate mud, absent in Basin 3. F = cave rafts, coated by $50 \mu \mathrm{m}$ dolomite overgrowths and quartz in Basin 1; raft fabric and underlying mammillaries destroyed by evaporative dolomite in Basin 3, which ends upward in dolomite botryoids and chalcedony.

$\mathrm{F}$ of Basin 3 includes fine-grained botryoidal dolomite with balls and clusters of chalcedony typical of evaporitic speleothems.

All basin fills terminate upward in dolomitized cave rafts (formerly calcite) lined with chalcedony. The mammillary wall crust (D) beneath Basin 3 has also been irregularly dolomitized (Fig. 21). These conditions probably signify late-stage drying and evaporation. In all three basins, $\mathrm{Fe}$ or $\mathrm{Mn}$ deposits contain fenestrae cemented with calcite (Fig. 20B). The fenestrae formed in soft sediment; they do not intersect fossils. Some are coated with two stages of cement separated by detrital material, so they were true voids. This texture is common in peritidal microbial mats, either from biogenic gas or grain bridging (Scholle \& Ulmer-Scholle, 2003). Most grains lie directly atop fenestrae without falling, which suggests biogenic gas. Alternatively, the voids may be partly tensional, because the contours of opposite walls crudely match, and they branch into desiccation cracks.

Fe-Mn oxides in the basin fills appear to be products of $\mathrm{H}_{2} \mathrm{SO}_{4}$ clay alteration. EDS scans show $\mathrm{Si}$ and Al peaks, as well as Fe and Mn. Some basins have overflowed, or have been breached by dissolution, so their contents dripped out. Ropy strands of microbial filaments, coated with $\mathrm{Fe}$ oxides, extend downward from them and have been coated by calcite (Fig. 22; Davis et al., 1990). The filaments resemble those of the acidophilic Leptospirillum ferrooxidans (Provencio $\&$ Polyak, 2001). Their presence implies that some basin fills had become anoxic and that oxidation, with microbial mediation, took place as the water drained out. Layer D of Basin 3 contains Fe oxide crystals that may be pyrite pseudomorphs, and SEM views of calcite mammillaries in the basin area show cubic pseudomorphs in solutional pores.
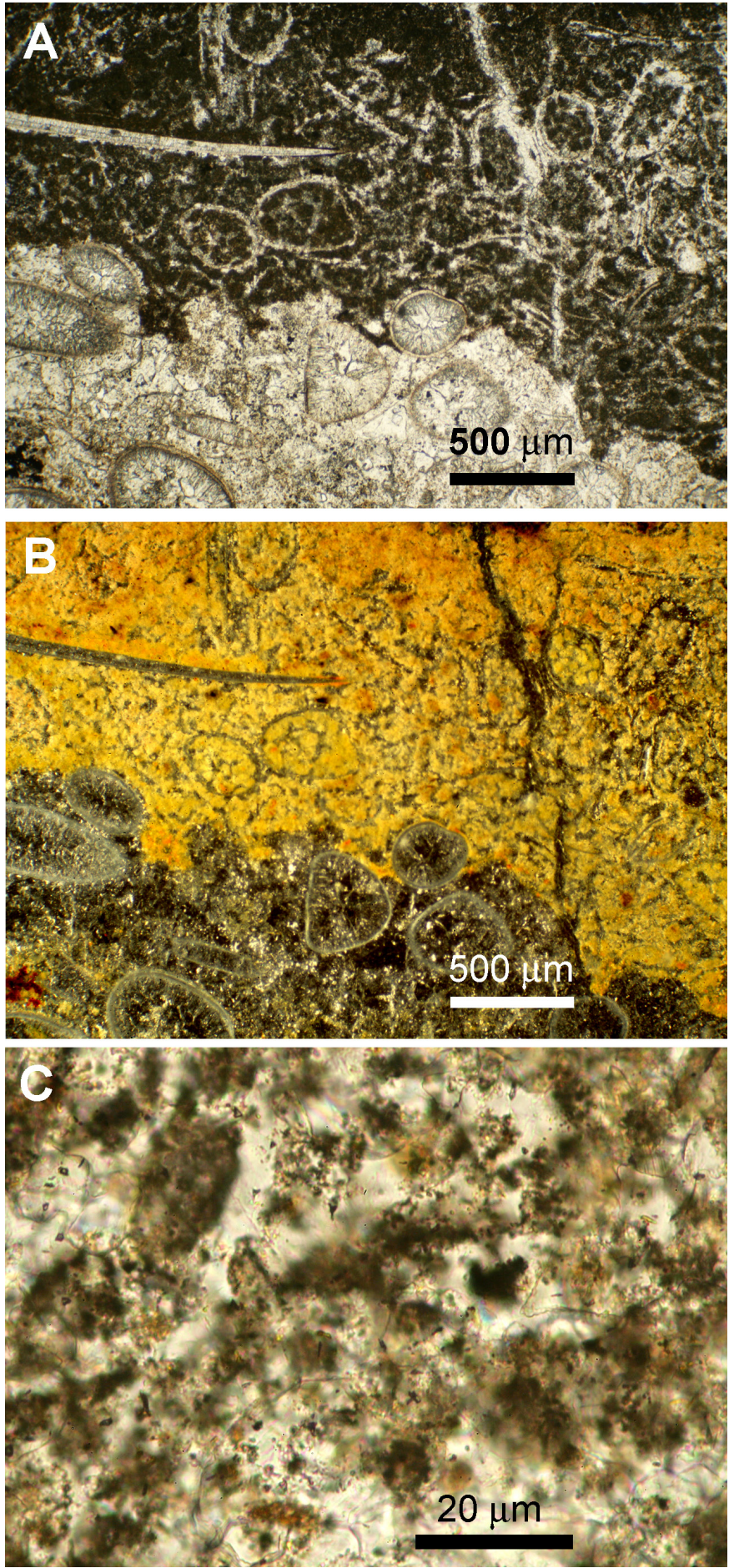

Fig. 19. Basin 2C of Fig. 18: Fe-oxide-rich matrix around fossil shells corroded from ceiling. Fe oxide appears mottled (microbially?). $A=P L, B=R L . C=$ enlarged view, $P L$. 


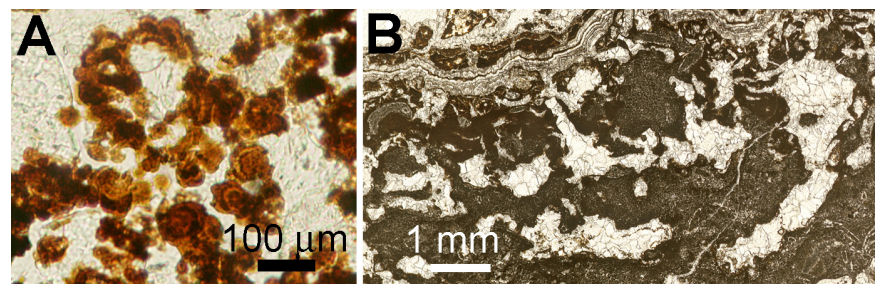

Fig. 20. Microbial textures in basin fill. A) Layered domal Mn-oxide bodies at top of layer E, Basin 2, Fig. 18. PL. B) Fenestrae in layer C of Basin 1, cemented by mammillary calcite at top left, PL.

\section{Calcite Replacement of Speleogenetic Gypsum}

In scattered locations, calcite has replaced speleogenetic gypsum. The calcite consists of $\sim 200 \mu \mathrm{m}$ rhombs or blocky cement generally attached to bedrock surfaces. It contains gypsum inclusions and diagnostic fabrics of speleogenetic gypsum, including wedges of altered bedrock rind, clay residue, and FeMn-rich strands. Some of the gypsum inclusions contain microscopic corroded calcite crystals (Fig. 23), showing the various generations of mineralization. The replacive calcite ends outward in a layered crust resembling that of speleothems. An example is located in Spider Cave near a former water level (Fig. 23C). Replacement apparently took place while gypsum was being partly dissolved by calcite-saturated water. Release of $\mathrm{Ca}^{2+}$ from the gypsum led to precipitation of calcite by the common-ion effect (Palmer \& Palmer, 2004). Dolomite is rarely precipitated by this process. In places calcite replacement has obscured earlier alteration fabrics (Fig. 23D). Isotopic values are not yet available for the replacive calcites.

\section{Mammillary Crusts}

Guadalupe caves contain a great variety of subaqueous and subaerial speleothems (Hill, 1987; Davis et al., 1990; Queen \& Melim, 2006). Most are omitted from this discussion (e.g. calcite deposits from meteoric infiltration) in favor of those less understood.

Calcite mammillaries up to about $25 \mathrm{~cm}$ thick are common in the lower levels of many Guadalupe caves (Figs. 24 \& 25). Deposited in standing water, they contain multiple layers, each precipitated over a wide vertical range (typically $>20 \mathrm{~m}$ ) like wallpaper. They coat all types of material, including the basin sediments described above. Their tops correlate over large areas and apparently represent former watertable stands, which correspond roughly to the lowest significant level of sulfuric acid speleogenesis $(\sim 1130$ $\mathrm{m}$ asl in Carlsbad and slightly higher in the Western Borehole of Lechuguilla). The age of mammillaries at Lake of the Clouds exceeds $600 \mathrm{ka}$ (from U/Th dating; unfavorable $\mathrm{U} / \mathrm{Pb}$ values prevent obtaining older dates; David Decker, Univ. of New Mexico, personal communication, 2011).

The growth of calcite mammillaries was periodically interrupted by thin black layers of Fe-Mn oxides. Each black layer is a few tens of $\mu \mathrm{m}$ thick, with up to 10 individual laminae. Oxide layers seem too uniform to have originated directly as sulfuric acid residue from clay, and many are remote from clay-rich backreef beds. Instead, dissolved $\mathrm{Fe}^{2+}$ and $\mathrm{Mn}^{2+}$ may have been carried into the cave periodically by anoxic water from depth and precipitated in the aerated cave. How- ever, EDS scans show that the Fe-Mn layers contain small amounts of $\mathrm{Si}$ and $\mathrm{Al}$, which may indicate that local Fe-Mn oxides supplied by $\mathrm{H}_{2} \mathrm{SO}_{4}$ clay alteration were dissolved when the pools were anoxic. Microscopy and EDS scans of the cave mammillaries show that calcite precipitation ceased while the Fe-Mn layers were deposited. Analysis of the relevant equilibria shows that an $\left(\mathrm{Fe}^{2+}+\mathrm{Mn}^{2+}\right)$ concentration of only 0.1 $\mathrm{mg} \mathrm{L}^{-1}$, when oxidized, can produce enough $\mathrm{H}^{+}$to neutralize all $\mathrm{HCO}_{3}{ }^{-}$in typical calcite-saturated cave pools and initiate carbonate dissolution.

Most Fe-Mn layers in the Guadalupes contain outward-facing shrub-like bodies apparently of microbial origin (Fig. 25D). Chafetz et al. (1998) describe nearly identical examples in shallow surface streams fed by warm springs. Mn-oxidizing and -reducing bacteria have been identified in both Lechuguilla (Northup et al., 2003) and Spider (Spilde et al., 2005) and are still viable. Inorganic oxidation of $\mathrm{Mn}$ requires a $\mathrm{pH}$ of about 8, whereas the presence of Mn-oxidizing microbes allows it to precipitate at near-neutral $\mathrm{pH}$ (Ehrlich, 1995).

The oxide layers appear to terminate downward, away from oxidizing conditions, and most do not extend upward beyond the mammillaries. However, thin discontinuous oxide deposits coat walls up to at least $1170 \mathrm{~m}$ in Lechuguilla (Fig. 17) and also some mammillaries below $1130 \mathrm{~m}$, leaving discrete water lines. Andrejchuk \& Klimchouk (2001) describe a related example in Ukraine, where 50 years of mine dewatering lowered the water table in a gypsum cave, causing

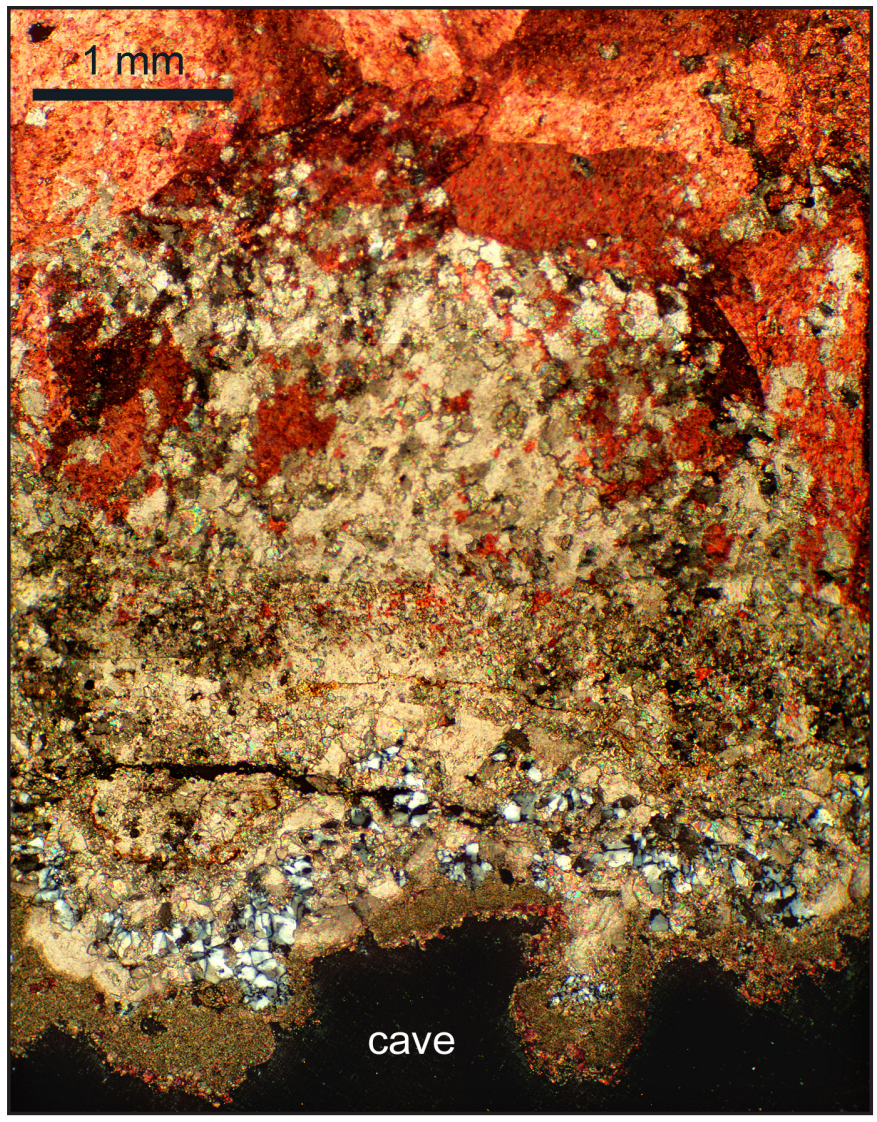

Fig. 21. Invasive dolomite replacement of mammillary crust and bedrock below Basin 3, Lechuguilla Cave. Note irregular replacement front. Dolomite ends outward in evaporative chalcedony and finely crystalline dolomite. XP, red stain for calcite. 


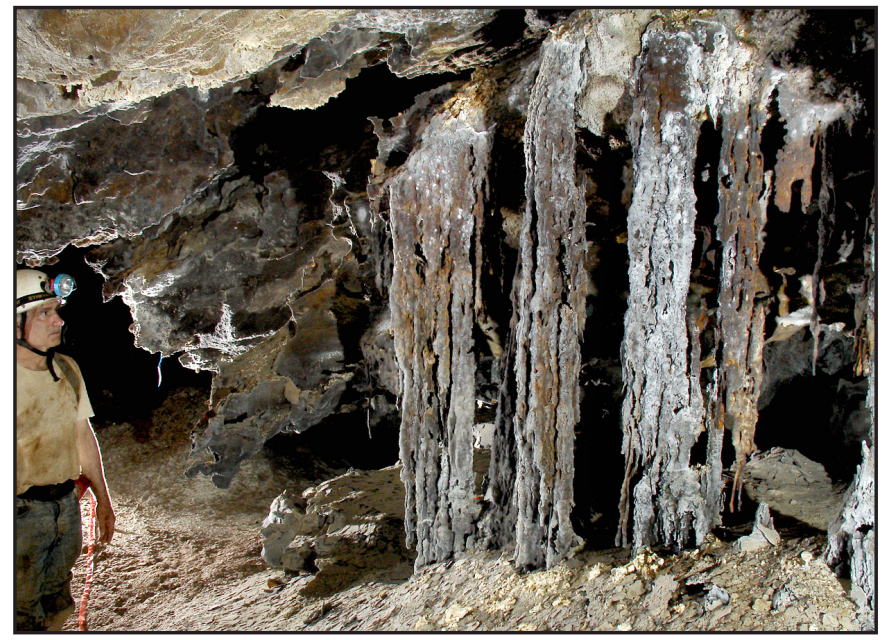

Fig. 22. Rusticles in the Near East of Lechuguilla Cave, have spilled from solution basins above to form the "Iron Curtain." These are bundles of microbial filaments lined with Fe-Mn oxides and coated by mammillary calcite (Photo by Mark Tracy).
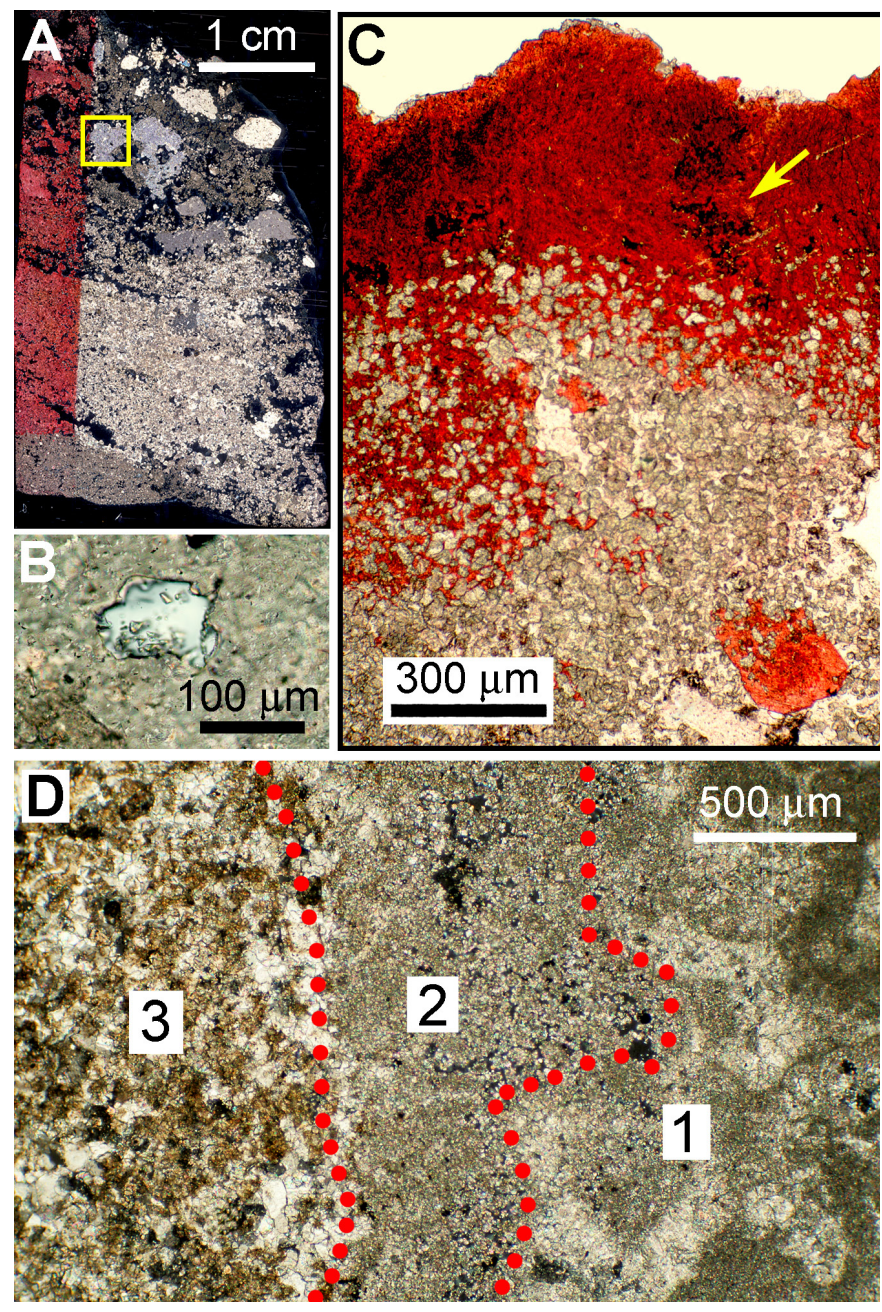

Fig. 23. Calcite replacement of gypsum. A) Calcite containing debris from $\mathrm{H}_{2} \mathrm{SO}_{4}$ dissolution, Lechuguilla Cave (box enlarged in B), XP, red stain for calcite. B) Gypsum inclusion (gray) in calcite shows replacement of gypsum, XP. C) Calcite replacement of $\mathrm{H}_{2} \mathrm{SO}_{4}$ gypsum crust, Spider Cave. Corroded bedrock and Fe-Mn oxide strands (arrow) float in calcite that grades outward into a layered speleothem. Red dye for calcite, PL. D) Lechuguilla, XP: 1 = limestone, 2 = micritic rind, 3 = granular calcite after gypsum, with remnants of micritic rind and Fe-Mn oxide.
Fe-Mn hydroxides to accumulate as yellow films on walls and as black deposits in clay beds.

After deposition of calcite mammillaries, evaporative dolomite replacement took place as water levels fell. In places dolomite formed overgrowths on the outer mammillary layer, and elsewhere it replaced calcite along crystal interfaces, penetrating mammillary layers to form a jagged contact and obliterating the original crystal fabric (Fig. 21).

Remaining mammillary pools are static, with very low $\mathrm{PCO}_{2}$ (mean $\left.=0.0006 \mathrm{~atm}\right)$. Low $\delta^{13} \mathrm{C}$ of mammillary calcite (Fig. 3, LG805, LG847) shows equilibrium with $\mathrm{CO}_{2}$ in the cave atmosphere. In contrast, vadose infiltration has much higher $\mathrm{PCO}_{2}$ and produces perched pools at a variety of levels. Rapid degassing in these pools causes lateral growth of shelfstone at the water surface and high $\delta^{13} \mathrm{C}$ values. Infiltrating water in Lechuguilla Cave ranges from oxic to suboxic, with minor concentrations of $\mathrm{Mn}$ but undetectable $\mathrm{Fe}$ (Levy, 2007). Fe-Mn deposits are rare in vadose pools because of comparatively uniform oxidation potential and a lack of anoxic recharge.

Villa Luz shows a contrast to the Guadalupe Fe-Mn coatings. Local reducing conditions occur in streams floored by dark gray sediment including detrital grains, authigenic pyrite, and carbonaceous muck, mainly from organic debris from skylights (rare in Guadalupe caves). $\mathrm{H}_{2} \mathrm{~S}$ is present at water depths $>15 \mathrm{~cm}$, oxygen is below detection limit, and walls are black with a continuous coating of finely crystalline $\mathrm{FeS}$ and $\mathrm{FeS}_{2}$. When exposed to air, the sulfides rapidly oxidize to sulfur and to Fe hydroxides and oxides as $\mu \mathrm{m}$-size crystals (Fig. 26). Except in certain mammillaries (Fig. 26 B \& C), our samples of Guadalupe wall coatings show no evidence of former pyrite.

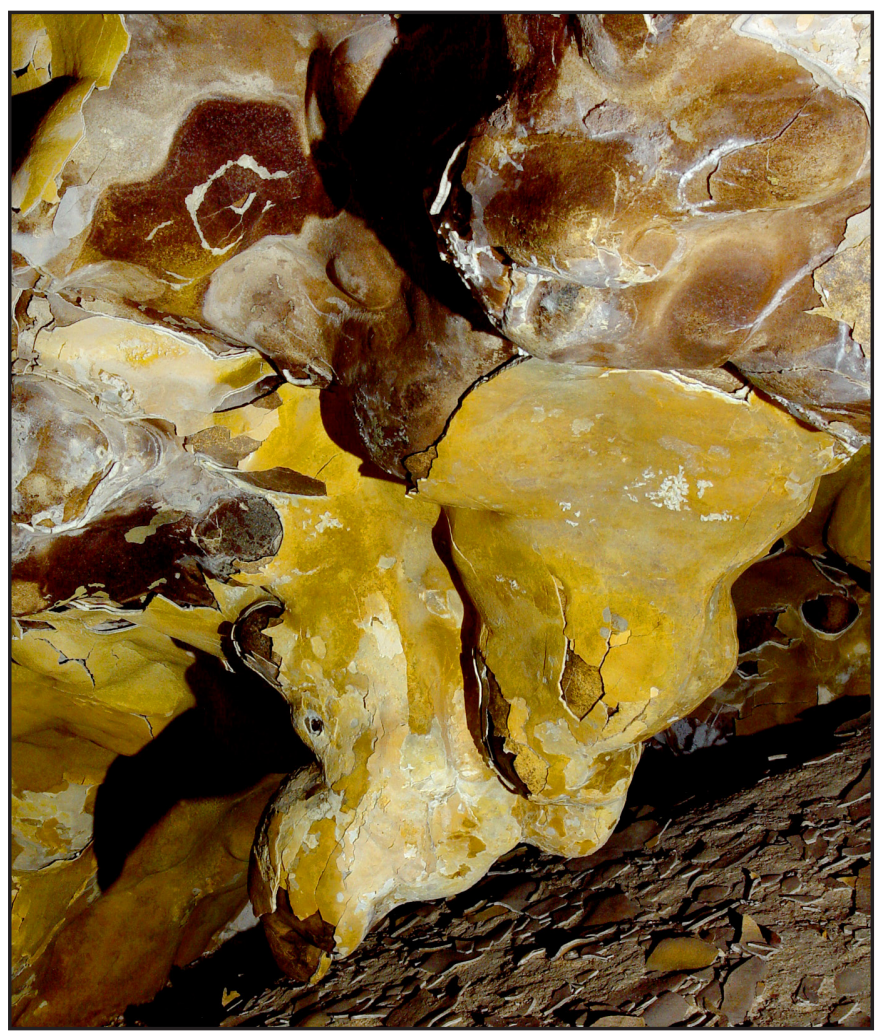

Fig. 24. Mammillary crust, Western Borehole, Lechuguilla Cave. Calcite sheets peel away from wall along Fe-Mn oxide laminae. Height of photo $\sim 2.5 \mathrm{~m}$. 

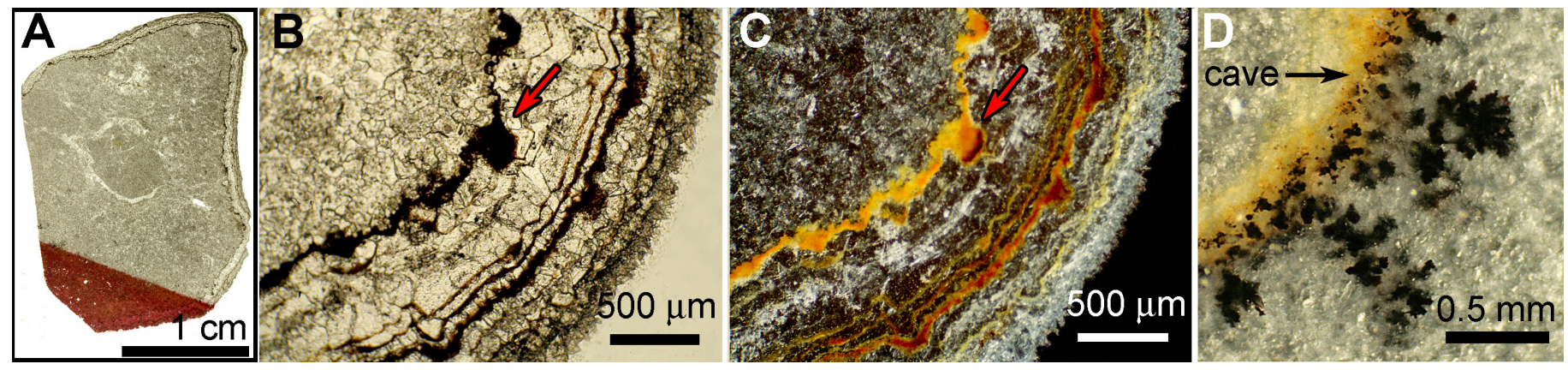

Fig. 25. Mammillary crust in the Near East of Lechuguilla Cave has at least nine layers of Fe-Mn oxides. A) Bedrock coated with crust, $\mathrm{PL}$, red stain for calcite. B) Enlarged view. Note domal, microbial (?) Fe-oxide-coated bodies (arrow). PL. C) Same, but RL. D) Layer in mammillary crust, Carlsbad, containing Fe-Mn-oxide shrubs, RL.

\section{Condensation Corrosion}

High internal relief in the Guadalupe caves supports atmospheric convection driven by temperature and humidity gradients. Relative humidity in Carlsbad ranges from 100\% to about 87\% (McLean, 1971; Ingraham et al., 1990). Evaporation from warm and deep levels leads to condensation on cooler surfaces above. Many cave ceilings and high-level speleothems are corroded by this process. For example, the ceiling of the steeply inclined passage to Lake of the Clouds is highly corroded, while mammillary crust coats the local floors and walls. Apparently as the lake level dropped, condensation corrosion extended to everlower elevations while mammillary crusts continued to form below. In places there are conspicuous subhorizontal boundaries between vadose speleothems and overlying corroded bedrock and speleothems (Fig. 27). Because most surfaces below the line are coated with botryoids (cave popcorn), this is known as the "popcorn line" (Hill, 1987; Queen, 1994, 2009b). Left Hand Tunnel contains a popcorn line about 3-5 m below the ceiling. Both thermal and humidity gradients are present. Two years of monitoring show relative humidities at or near $100 \%$ near the ceiling, and 87-96\% near the floor, with almost uniform temperatures of $15-16{ }^{\circ} \mathrm{C}$ throughout (Paul Burger, National Park Service, personal communication, 2011). At the underlying Lake of the Clouds the mean temperature is $20^{\circ} \mathrm{C}$, which provides a strong thermal gradient.

Evaporation from pools can also be demonstrated isotopically by a decrease in $\delta^{18} \mathrm{O}$ values in the water vapor relative to pool water. Water in Lake of the Clouds has $\delta^{18} \mathrm{O} \sim-6.8 \%$ o VSMOW (Ingraham et al., 1990), and if the overlying vapor were in equilibrium with the pool, the vapor would have $\delta^{18} \mathrm{O}$ of $-16.4 \%$ o (computational method in Faure \& Mensing, 2005). In this case no more evaporation would be possible. Instead, the overlying water vapor has $\delta^{18} \mathrm{O} \sim-18.2 \%$ o (Ingraham et al., 1990), lower than the equilibrium value, so further evaporation is possible.

Condensation greatly affects the isotopic signatures of both the water and corroded material. Condensation can shift the $\delta^{18} \mathrm{O}$ of evaporative water as much as $+10 \%$ o (Bottinga \& Craig, 1969). In surface rainfall the earliest drops remove the most positive
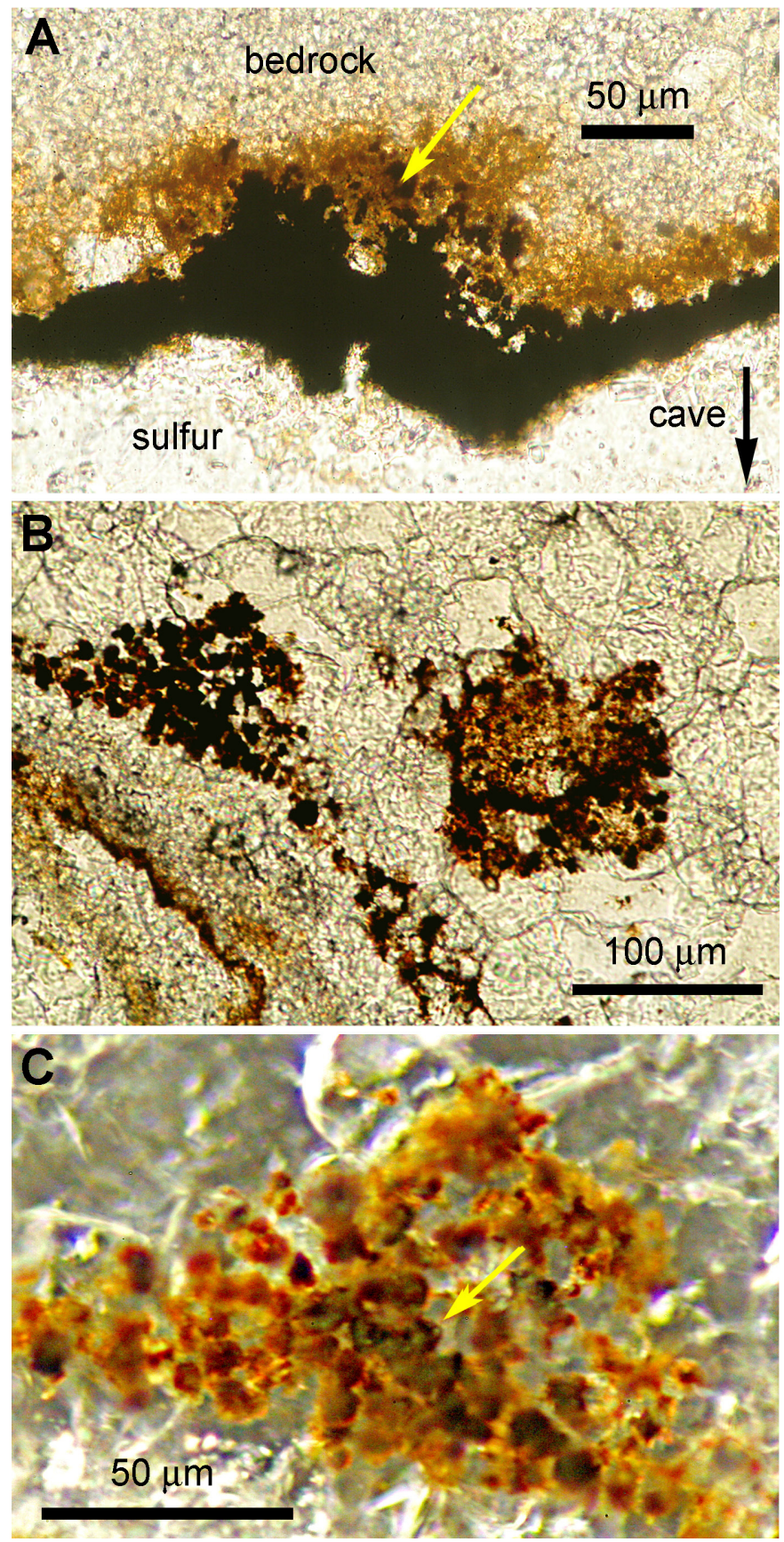

Fig. 26. Pyrite wall crust. A) Villa Luz. Wall coating below water level consists of Fe oxides after pyrite near $\mathrm{H}_{2} \mathrm{~S}$ inlet, $\mathrm{PL}$. Fe oxide penetrates bedrock. Note lack of calcite precipitates and tiny Fe oxide cubes after pyrite (arrow). B) Outermost mammillary layer in Basin 3, Lechuguilla (Fig. 18), contains $5 \mu \mathrm{m}$ Fe-oxide crystals, linked in a branching (microbial?) mass, similar to A, PL. Cave wall is toward the top. C) Enlargement of B, RL. Pyrite may have resulted from local sulfate reduction. 


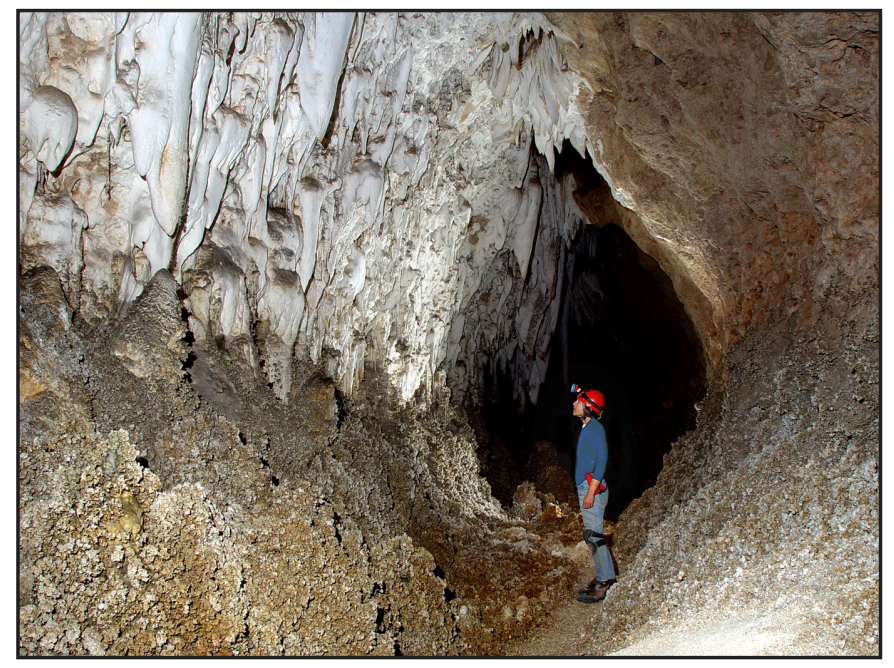

Fig. 27. The "popcorn line" in Left Hand Tunnel, Carlsbad Cavern. Walls and ceiling above are corroded, while botryoidal calcite is precipitated below.

$\delta^{18} \mathrm{O}$ from the vapor, and later ones are more negative; but the impact of moist air against a cold surface can bypass some of this fractionation by quickly condensing moisture with average isotopic values. Corroded surfaces show diminished $\delta^{18} \mathrm{O}$ and $\delta^{13} \mathrm{C}$ relative to the host carbonates (Fig. 3; see also the Micritic Rinds section and Sarbu \& Lascu, 1997). The effect, but not the process, resembles the micritization beneath gypsum crusts during sulfuric acid speleogenesis. Condensation corrosion produces loose grains that easily fall away. In the weak carbonic acid there is much differential solution between grains of different crystal size or composition, and clay alteration is limited. As condensation corrosion proceeds, the isotopic shift caused by bedrock weathering is apparently cumulative, e.g., from $\mathrm{H} 1$ to $\mathrm{H} 2$ in Fig. 3, representing several increasingly weathered samples (Hill, 1987). Effects are most conspicuous in clay-rich back-reef beds, which produce a fluffy coating of red, yellow, brown and black, consisting of quartz silt, clay, and Fe-Mn oxides (Fig. 28). Purer carbonate bedrock simply weathers to light gray powder. The clay-rich beds in Spider Cave were apparently first altered in sulfuric acid conditions and later modified by condensation corrosion in $\mathrm{CO}_{2}$-rich air (Fig. 29A). Corroded zones are fertile ground for microbially mediated $\mathrm{Fe}-\mathrm{Mn}$ reactions (Northup et al., 2003). Alternation between speleothem growth and corrosion probably indicates wet-dry cycles, with carbonate precipitation during wet periods and corrosion dominating in dry periods.

Micritization by condensation water produces intricate internal solutional features at $\mu \mathrm{m}$ scales, a typical effect of capillary water (Fig. 29B). Many subaerial calcite speleothems have acquired white micritized rinds, most notably in Spider Cave (Fig. 30A). Isotopes from a broken stalactite show typical opensystem calcite values for the unweathered portion (Fig. 3, SP808B), with offsets of $-0.68 \%$ o $\left(\delta^{18} \mathrm{O}\right)$ and $-2.1 \%$ o $\left(\delta^{13} \mathrm{C}\right)$ in the $5 \mathrm{~mm}$ white rind (SP808A). The significant change in $\delta^{13} \mathrm{C}$ shows interaction with subaerial $\mathrm{CO}_{2}$. Much corroded material has fallen to the floor to form a soft and moist granular paste. It can produce layers on underlying surfaces, or, on walls, blobs with finger-like spears shaped by dripping con- densation water. Where evaporation is limited, cementation is poor or absent, because condensation water is already at equilibrium with cave air and $\mathrm{CO}_{2}$ degassing is insignificant.

Drip cones of calcite and other carbonate minerals can grow on the floor by evaporation. Most have central drip holes maintained by still-aggressive condensation water. Many cones have been largely replaced by evaporative dolomite and terminate outward in euhedral quartz. Some also show interaction with meteoric water.

When calcite precipitates, its $\delta^{18} \mathrm{O}$ is about $30 \%$ higher than in the host water, depending on temperature (Friedman \& O'Neil, 1977). The initial calcite in Carlsbad drip cones should therefore have $\delta^{18} \mathrm{O}$ of roughly $-8 \%$ o VPB, more negative than typical dripstone. But as evaporation proceeds, ${ }^{16} \mathrm{O}$ is selectively removed from the water and $\delta^{18} \mathrm{O}$ in the deposits increases (e.g., to $-4.81 \%$ o for $\mathrm{CB} 808$ and $-3.74 \%$ or CB905 in Fig. 3). This positive shift overlaps the values for speleothems formed in and around meteoric pools, but the two types of deposits can be distinguished by their shape and composition.

Vents are tubes or channels dissolved in bedrock by condensation corrosion in constricted areas. Many intersect rills formed by previous sulfuric acid. Vents are bordered by flaring rims of precipitates, usually oriented toward cave entrances, and apparently formed by evaporation of condensation water that wicks out of the corroded area. Samples CB803 and CB813 (Fig. 3) are evaporative deposits from condensation water that had corroded a rim. Note the highly negative isotopic ratios. However, an upward-facing vent near the Left Hand Tunnel has a popcorn rim with more positive isotopes, which suggest precipitation from meteoric water (Fig. 3, CB932). This popcorn may pre-date the vent.

\section{Modification of Speleothems by Evaporation and Recrystallization}

Many speleothems in Guadalupe caves terminate in evaporative precipitates that increase in $\mathrm{Mg}$ content away from their water sources (whether mete-

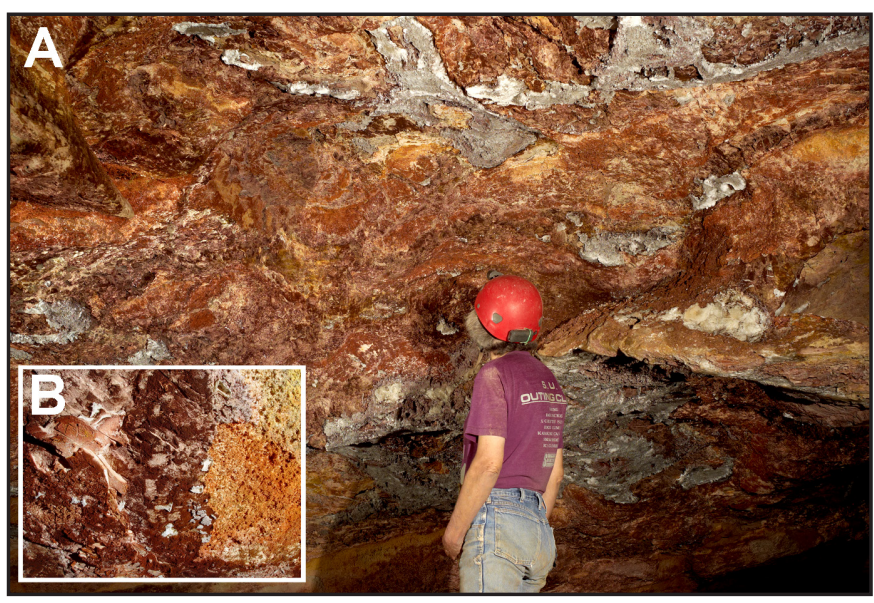

Fig. 28: Residue from condensation corrosion in Spider Cave. A) Passage in backreef beds weathering to silt, clay, and Fe-Mn oxides. Much residue falls to the floor. Carbonate bedrock weathers light gray, finely crystalline, and fluffy. Calcite spar in bedrock is corroded to needles along the cleavage. B) Enlarged view; width $=0.3 \mathrm{~m}$. 


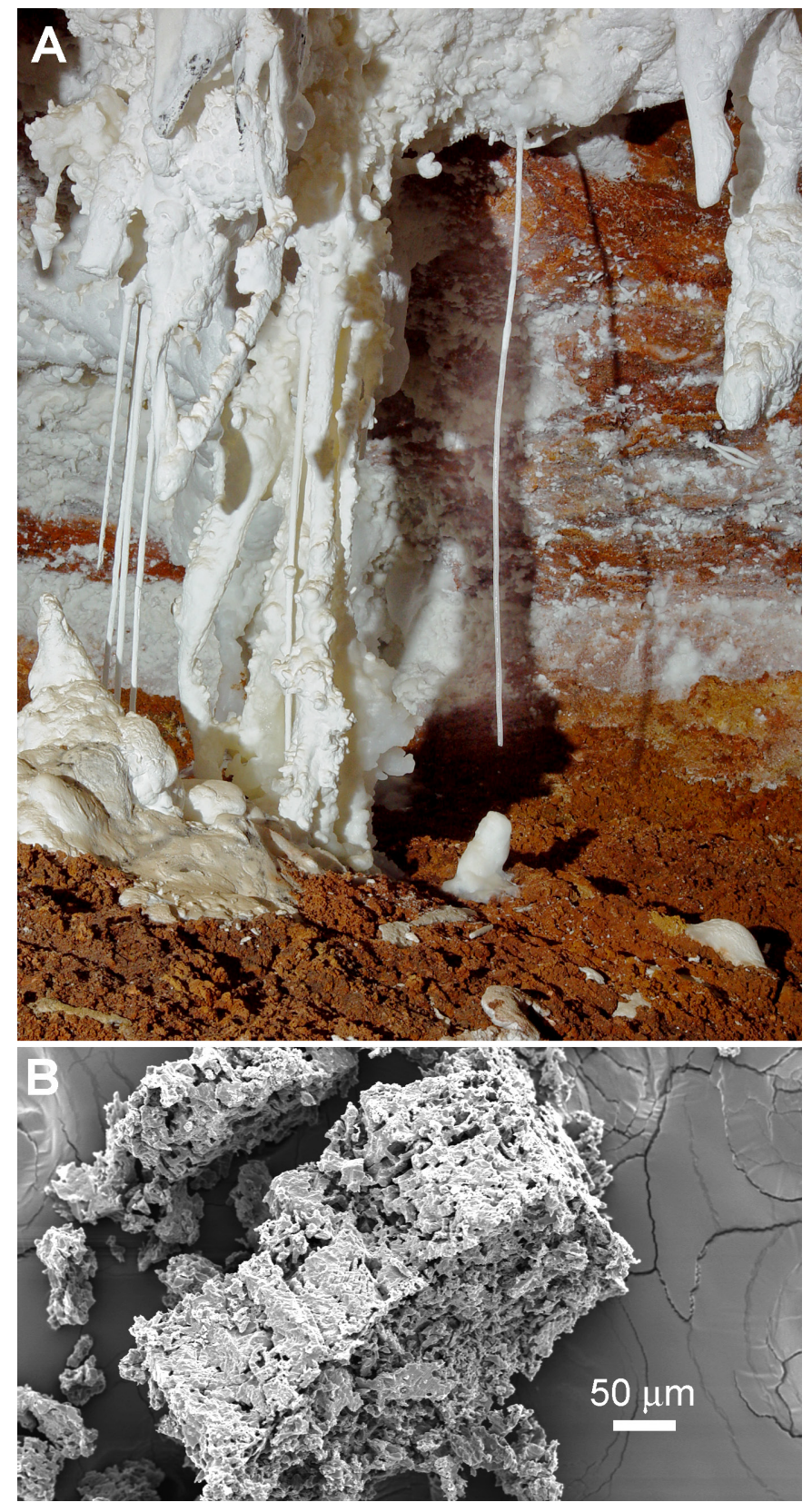

Fig. 29. A) Vadose speleothems in Spider corroded by condensation water, overlying older residue of silty clay and Fe-Mn oxides. Width $=0.7 \mathrm{~m}$. B) SEM image of speleothem corroded by $\mathrm{CO}_{2}$-rich condensation moisture. Intricate internal skeletal porosity is typical. The earlier $\mathrm{H}_{2} \mathrm{SO}_{4}$ micritic rind predates speleothems and is usually indurated (see Fig. 4).

oric infiltration or condensation). Carbonate deposits around evaporative pools, fed by meteoric drips, grade outward from pasty hydromagnesite, huntite, dolomite and aragonite to indurated popcorn. Far from the water source, these minerals are accompanied by montmorillonite (smectite) and palygorskite clays typical of low-moisture alkaline conditions. The latest evaporative deposits are typically euhedral quartz, chalcedony, or opal. Many speleothems, including mammillaries, end outward in dolomite. Some evaporative aragonite and dolomite contain scattered $\sim 500$ $\mu \mathrm{m}$ barite crystals (by-product of acid clay alteration?) accompanied by $\mathrm{Fe}-\mathrm{Mn}$ oxides and siliceous residue (Fig. 31A). See Polyak \& Provencio (2001) for a description of other evaporative minerals.
Evaporation has been much greater in well-aerated Carlsbad Cavern than in Lechuguilla Cave, as shown by the oxygen isotopes of pool water. In Carlsbad pools, $\delta^{18} \mathrm{O}=-3.6$ to $-6.8 \%$ VSMOW, and in Lechuguilla pools it is -7.0 to $-8.0 \%$ VSMOW (Newton et al., 2001). This difference is also transmitted to carbonate pool deposits. At $17{ }^{\circ} \mathrm{C}$ these pools would precipitate calcite with $\delta^{18} \mathrm{O}=-3.5$ to $-6.6 \%$ VPDB and -6.8 to $-7.7 \%$ o VPDB respectively (Fig. 3).

Some carbonate speleothems have recrystallized to a glassy texture with clear euhedral crystals lacking growth layers. They appear to form in nearly closed cave environments, in which the water films on the speleothems, and perhaps interstitial water within, is very close to calcite saturation and in $\mathrm{CO}_{2}$ equilibrium with the cave air, so mass transfer between water and speleothems is balanced. Glassy popcorn (Fig. 3, LG 344 and Fig. 30B) has an abnormally low $\delta^{13} \mathrm{C}$ that reveals long-term carbon exchange between cave-air $\mathrm{CO}_{2}$ and calcite, with slight evaporation but no degassing. Spider Cave contains many calcite speleothems that have been recrystallized in this way. The cave has a single small entrance periodically blocked in the past by mass wasting, and recrystallization may have occurred during a period of lengthy blockage. Slow dripwater maintained a relatively high $\delta^{13} \mathrm{C}$ in the speleothems (e.g. Fig 3, SP808b). Later micritization turned the speleothem walls a ghostly white (e.g. Fig. 29A). The isotopic shift suggests that condensation corrosion was responsible (Fig. 3, SP808a).

\section{Evidence for Late-Stage Hypogenic Gases}

One of our main goals was to determine the manner in which sulfuric acid dissolution ceased in the Guadalupes; but at the end of this study we have only begun to find an answer. In brief, the last stages of sulfuric acid dissolution overlapped both temporally and spatially with what are usually considered postspeleogenetic events such as mammillary deposition. Below the levels of alunite-dated $\mathrm{H}_{2} \mathrm{SO}_{4}$ features and mammillaries, steep rifts extend downward that show evidence for very late sulfuric acid enlargement. For example, in Lechuguilla, the rift that extends well below the lowest mammillaries down to the water table in the Southeastern Branch contains bare, highly corroded bedrock walls with no mammillaries. Its lower
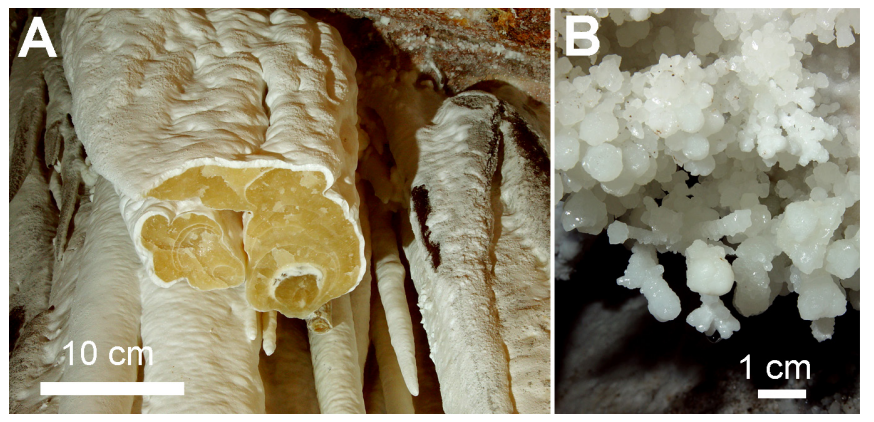

Fig. 30. Recrystallized speleothems. A) Vandalized stalagmite in Spider with white micritized rind overlying recrystallized interior. Both $\delta^{13} \mathrm{C}$ and $\delta^{18} \mathrm{O}$ are lower in the rind (Fig. 3, SP 808a-b). B) Glassy recrystallized popcorn (Fig. 3, LG 344) has anomalously low $\delta^{13} \mathrm{C}$ from precipitation in condensation water, with almost no $\mathrm{CO}_{2}$ degassing. 


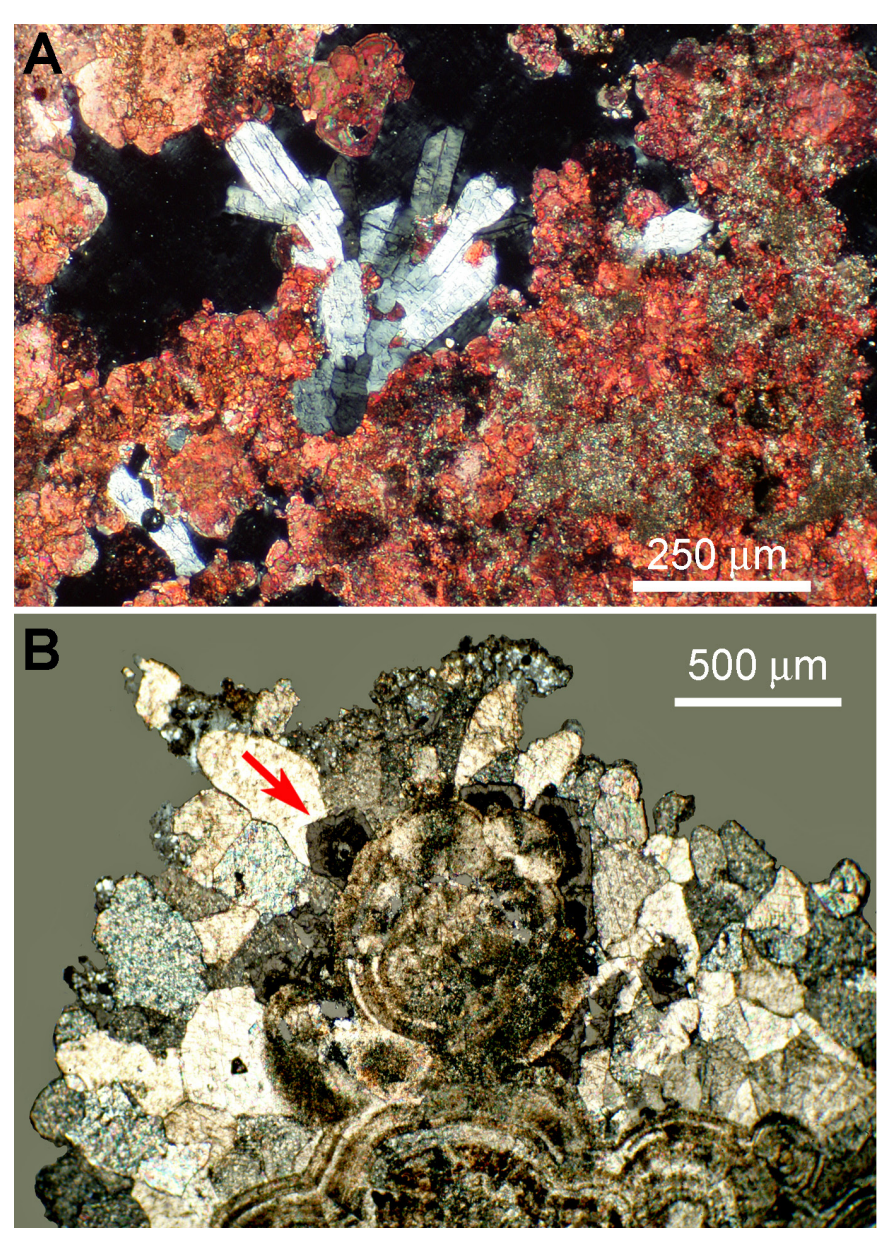

Fig. 31. Late-stage exotic minerals. A) Barite (gray) in floor crust, Left Hand Tunnel, Carlsbad Cavern. Red stain for calcite, XP. B) Fluorite crystals (black, isotropic) line carbonate popcorn, Lechuguilla, XP. Fluorite crystals are also found on gypsum elsewhere in the cave.

half contains many solution basins, and near the bottom are rafts and folia, but no mammillaries. This and a few similar routes were active long after most of the $4 \mathrm{Ma}$ level (at roughly $1130 \mathrm{~m}$ in Fig. 2) had ceased to enlarge.

So far we see no evidence of anomalous sources of $\mathrm{CO}_{2}$. These would likely produce features with significantly lower $\delta^{13} \mathrm{C}$ than those in Fig. 3. For example, Kirkland \& Evans (1976) ascribe the origin of limestone buttes in the nearby Delaware Basin to reduction of gypsum by rising natural gas, resulting in a mean $\delta^{13} \mathrm{C}$ of $-24 \%$, far below the values in Fig. 3 . Trace amounts of gases such as $\mathrm{SO}_{2}, \mathrm{COS}$, and $\mathrm{CS}_{2}$ are present in Lechuguilla (LaRock \& Cunningham, 1990), but there is so far no evidence that they have affected the cave or pose a danger.

The only mineralogical evidence we find for latestage hypogenic gases (other than $\mathrm{H}_{2} \mathrm{~S}$ ) consists of sparsely scattered $200 \mu \mathrm{m}$ crystals of fluorite $\left(\mathrm{CaF}_{2}\right)$ on surfaces of gypsum and carbonate popcorn (Fig. 31B). The fluorite is not detrital, because its crystals have nucleated on the substrate, with euhedral faces extending outward. Concentration of fluoride is best explained by an influx of HF gas. Absorption of $\mathrm{HF}$ by droplets of condensation water in windy areas can concentrate the hydrofluoric acid and allow reactions with Ca-bearing minerals.
$\mathrm{HF}$ gas can be liberated by the attack of fluorinebearing minerals by $\mathrm{H}_{2} \mathrm{~S}$ or $\mathrm{H}_{2} \mathrm{SO}_{4}$ (Maltsev and Korshunov, 1998). We first considered detrital fluorapatite $\left[\mathrm{Ca}_{5}\left(\mathrm{PO}_{4}\right)_{3} \mathrm{~F}\right]$ as a possible source, but this is rare in the Guadalupes. It is more likely that HF was released by deep-seated processes on the fringe of the Rio Grande Rift zone (Fig. 1). Leuth et al. (2005) describe mines in the rift zone that contain thermal deposits such as fluorite, jarosite, and barite, which coincide in age with major speleogenetic episodes in the Guadalupes dated by Polyak et al. (1998) at 12-11 Ma and 6-4 Ma. DuChene \& Cunningham (2006) suggest that the Guadalupe caves formed when their catchment area extended much farther to the west and included known petroleum-related sulfide sources. Most of this plateau was gradually down-faulted in the late Neogene, leaving the caves as inactive relics with only a small remnant of their former recharge. Fluorite crystals support the relation between the rift zone and the caves, and the possibility of upward leakage of exotic gases during recent minor tectonic pulses.

\section{CONCLUSIONS}

Micro-scale petrographic mapping is shown to be an efficient way to reveal the complex geochemical evolution of hypogenetic caves such as those in the Guadalupe Mountains. Identifying mineral phases and relationships is the first step toward interpreting geologic processes. From there, the most likely hypotheses can be tested quantitatively with the aid of equilibrium chemistry and stable isotopes. The processes described here have greatly affected how the caves look today.

Numerical chronology has not been considered here. Available dates are few and widely scattered, and the history of events is complicated by spatial and temporal overlap and by fluctuating intensity and occasional repetition. Scattered late stages of sulfuric acid enlargement were contemporaneous with depositional features such as mammillaries at similar elevations elsewhere in the caves. Observations in this paper should help to decipher this genetic history. They may also improve the efficiency of numerical dating and paleoclimatology, and aid the recognition of diagnostic features in other sulfuric acid caves.

\section{ACKNOWLEDGMENTS}

Thanks to fellow researchers Victor Polyak, J. Michael Queen, Carol Hill, Donald Davis, Laura Rosales Legarde, Bogdan P. Onac, and Paul Burger for discussion of concepts over many years; Richard Zopf, Rick Olson, Paul Rubin, Mark Tracy, Brandon Taylor, Steve Worthington, Richard Maire, JeanFrançois Pernette, and Yves Prunier for help with the geologic surveys; Carlsbad Caverns National Park staff Stan Allison, Dale Pate, and Jason Walz for 1ogistical help and Paul Burger for humidity and temperature data; Tom Kraemer (U.S. Geological Survey) for O-H isotopic data; John Andersland (Western Kentucky University) for help with SEM work; and the State University of New York Research Foundation for covering laboratory expenses. Thanks also to three anonymous reviewers whose suggestions helped to clarify the text. 


\section{REFERENCES}

Andrejchuk V. \& Klimchouk A., 2001 - Geomicrobiology and redox geochemistry of the karstified Miocene gypsum aquifer, western Ukraine: the study from Zoloushka Cave. Geomicrobiology Journal, 18: 275-295.

http://dx.doi.org/10.1080/01490450152467796

Asmerom Y., Polyak V., Burns S. \& Rassmussen J., 2007 - Solar forcing of Holocene climate: new insights from a speleothem record, southwestern United States. Geology, 35 (1): 1-4. http://dx.doi.org/10.1130/G22865A.1

Blatt H., Middleton G. \& Murray R., 1980 - Origin of sedimentary rocks ( $2^{\text {nd }}$ ed). Prentice-Hall, Englewood Cliffs, NJ, 782 p.

Bottinga Y. \& Craig H., 1969 - Oxygen isotope fractionation between $\mathrm{CO}_{2}$ and water and the isotopic composition of marine atmospheric $\mathrm{CO}_{2}$. Earth and Planetary Science Letters, 5: 285-295.

http://dx.doi.org/10.1016/S0012-821X(68)80054-8

Brook G.A., Ellwood B., Railsback L. \& Cowart J., 2006 - A 164 ka record of environmental change in the American Southwest from a Carlsbad Cavern speleothem. Palaeogeography, Palaeoclimatology, Palaeoecology, 237: 483-507. http://dx.doi.org/10.1016/j.palaeo.2006.01.001

Chafetz H., Akdim B., Julia R. \& Reid A., $1998-M n-$ and Fe-rich black travertine shrubs: bacterially (and nanobacterially) induced precipitates. Journal of Sedimentary Research, 68: 404-412.

Davis D.G., 1980 - Cave development in the Guadalupe Mountains: a critical review of recent hypotheses. National Speleological Society, NSS Bulletin, 42 (3): 42-48.

Davis D.G., Palmer M.V. \& Palmer, A.N., 1990 - Extraordinary subaqueous speleothems in Lechuguilla Cave, New Mexico. National Speleological Society, NSS Bulletin, 52 (2): 70-86.

Deines P., Langmuir D. \& Harmon R., 1974 - Stable carbon isotope ratios and the existence of a gas phase in the evolution of carbonate ground waters. Geochimica et Cosmochimica Acta, 38: 1147-1164. http://dx.doi.org/10.1016/0016-7037(74)90010-6

DuChene H.R. \& Cunningham K.I., 2006 - Tectonic influences on speleogenesis in the Guadalupe Mountains, New Mexico and Texas. In: Land L., Leuth V., Raatz W., Boston P. \& Love D. (Eds)., Caves and karst of southeastern New Mexico. New Mexico Geological Society, 57th Field Conference: 211-218.

Egemeier S., 1987 - A theory for the origin of Carlsbad Caverns. National Speleological Society, NSS Bulletin, 49: 73-76.

Ehrlich H.L., 1995 - Geomicrobiology (3rd ed).. Marcel Dekker, New York, 719 p.

Engel A.S., 2004 - Microbial contributions to cave formation: new insights into sulfuric acid speleogenesis. Geology, 32 (5): 369-322.

http://dx.doi.org/10.1130/G20288.1

Fairchild, J. \& Baker, A., 2012 - Speleothem science: from processes to past environments. John Wiley \& Sons, London, $448 \mathrm{p}$.

http://dx.doi.org/10.1002/9781444361094

Faure G., 1998 - Principles and applications of geochemistry (2nd ed).. Prentice Hall, Upper Saddle River, NJ, 600 p.
Faure G. \& Mensing T., 2005 - Isotopes: principles and applications (3rd ed).. John Wiley \& Sons, Hoboken, NJ, 897 p.

Forbes J.R., 2000 - Geochemistry of Carlsbad Cavern pool waters, Guadalupe Mountains, New Mexico. Journal of Cave and Karst Studies, 62: 127-134.

Friedman I. \& O’Neil J.R., 1977 - Compilation of stable isotope fractionation factors of geochemical interest. U.S. Geological Survey Professional Paper 440-KK: $49 \mathrm{p}$.

Galdenzi S., Menichetti M. \& Forti P., 1997 - La corrosione di placchette calcaree ad opera de acque ulfuree: dati sperimentali in ambiente ipogeo. International Union of Speleology, Proceedings of 12th International Congress of Speleology, La Chaux-de-Fonds, Switzerland: 187-190.

Gonzáles L.A. \& Lohmann K.C., 1988 - Controls on mineralogy and composition of spelean carbonates: Carlsbad Caverns, New Mexico. In: James N. \& Choquette P. (Eds)., Paleokarst. New York: Springer-Verlag: 81-101.

Hardie L.A, 1967 - The gypsum-anhydrite equilibrium at one atmosphere pressure. American Mineralogist, 52: 171-200.

Hill C.A., 1987 - Geology of Carlsbad Cavern and other caves in the Guadalupe Mountains, New Mexico and Texas. New Mexico Bureau of Mines and Mineral Resources Bulletin, 117: 150 p.

Hill C.A., 1996 - Geology of the Delaware Basin, Guadalupe, Apache, and Glass Mountains, New Mexico and West Texas. Society for Sedimentary Geology, Permian Basin Section, Publication 96-39: 480 p.

Hose L.D., Palmer A.N., Palmer M.V., Northup D.E., Boston P.J. \& DuChene H.R., 2000 - Microbiology and geochemistry in a hydrogen-sulphide-rich karst environment. Chemical Geology, 169: 399-423. http://dx.doi.org/10.1016/S0009-2541(00)00217-5

Hoy R.N. \& Gross G.W., 1982 - A baseline study of oxygen-18 and deuterium in the Roswell, New Mexico groundwater basin. New Mexico Water Resources Research Institute Report, 144: 95 p.

Ingraham N.L., Chapman J.B. \& Hess, J.W., 1990 Stable isotopes in cave pool systems: Carlsbad Cavern, New Mexico, USA. Chemical Geology, 86: 6574.

Jagnow D., 1979 - Cavern development in the Guadalupe Mountains. Cave Research Foundation, Columbus, Ohio, 55 p.

Kirkland D.W. \& Evans R., 1976 - Origin of limestone buttes, Gypsum Plain, Culberson County, Texas. American Association of Petroleum Geologists Bulletin, 60 (11): 2005-2018.

LaRock E. \& Cunningham K.I., 1990 - The October 1999 Lechuguilla Microclimate study field trip. Denver, Colorado: National Speleological Society, Rocky Mountain Caving, 7: 27-33.

Leuth V.W., Rye R.O. \& Peters L., 2005 - "Sour gas" hydrothermal jarosite: ancient to modern acid-sulfate mineralization in the southern Rio Grande Rift. Chemical Geology, 215: 339-360.

http://dx.doi.org/10.1016/j.chemgeo.2004.06.042

Levy D.B., 2007 - Oxidation-reduction chemistry of Lechuguilla Cave seepage. Journal of Cave and Karst Studies, 69 (2): 351-358. 
Lohmann K.C., 1988 - Geochemical patterns of meteoric diagenetic systems and their application to studies of paleokarst. In: James N. \& Choquette P. (Eds)., Paleokarst. New York: Springer-Verlag: 58-80.

Luiszer F.G., 2009 - Speleogenesis of Cave of the Winds, Manitou Springs, Colorado. In: Engel A.S. \& Engel S.A. (Eds)., Select field guides to cave and karst lands of the United States. Leesburg, Va.: Karst Waters Institute, Special Publication 15: 119-132.

Maltsev V. \& Korshunov V., 1998 - Geochemistry of fluorite and related features of the Kugitangtou Ridge caves, Turkmenistan. Journal of Cave and Karst Studies, 60: 151-155.

Mandrikova N.T., Perozio G.N. \& Fedyunina V., 1975 Synthesis of protodolomite. Mineralogy, 220: 121-123.

McLean J.S., 1971 - The microclimate in Carlsbad Caverns, New Mexico. U.S. Geological Survey, Denver, Colorado, Open File Report 71-198: 67 p.

Newton B.T., Campbell A.R., Turin H.J., Phillips F.M. \& Plummer M.A., 2001 - Stable isotopic investigation of cave pools in Carlsbad Caverns National Park, NM. Geological Society of America, Rocky Mountain and South-Central Sections, Abstracts with Programs, 33 (5): 14.

Northup D.E., Dahm C.N., Melim L.A., Spilde M.N., Crossey I.J., Lavoie K.H., Mallory L.M., Boston P.J., Cunningham K.I. \& Barns S.M., 2000 - Evidence for geomicrobiological interactions in Guadalupe caves. Journal of Cave and Karst Studies, 62 (2): 80-90.

Northup D.E., Barns S., Yu L., Spilde M., Schelble R., Dano K., Crossey L., Connolly C., Boston P., Natvig D. \& Dahm C., 2003 - Diverse microbial communities inhabiting ferromanganese deposits in Lechuguilla and Spider Caves. Environmental Microbiology, 5 (11): 1071-1086.

http://dx.doi.org/10.1046/j.1462-2920.2003.00500.x

Palmer A.N., 1991 - Origin and morphology of limestone caves. Geological Society of America Bulletin 103 (1): 1-21.

http://dx.doi.org/10.1130/0016-7606(1991) 103<0001:OAMOLC >2.3.CO;2

Palmer A.N., 2007 - Cave Geology. Cave Books, Dayton, Ohio, $454 \mathrm{p}$.

Palmer A.N. \& Palmer M.V., 2000 - Hydrochemical interpretation of cave patterns in the Guadalupe Mountains, New Mexico. Journal of Cave and Karst Studies 62 (2): 91-108.

Palmer A.N. \& Palmer M.V., 2004 - Sulfate-Carbonate Interactions in the Development of Karst. Northeastern Geology \& Environmental Sciences, 26 (1\&2): 93-106.

Polyak V.J., 1992 - The mineralogy, petrography and diagenesis of carbonate speleothems from caves in the Guadalupe Mountains, New Mexico. MS thesis, Texas Tech University, Lubbock, TX: 165 p.

Polyak V.J., McIntosh W.C., Güven N. \& Provencio P.P., 1998 - Age and origin of Carlsbad Cavern and related caves from ${ }^{40} \mathrm{Ar} /{ }^{39} \mathrm{Ar}$ of alunite. Science, 279: 1919-1922.

http://dx.doi.org/10.1126/science.279.5358.1919

Polyak V.J. \& Güven N. 2000 - Clays in caves of the Guadalupe Mountains, New Mexico. Journal of Cave and Karst Studies, 62 (2): 120-126.
Polyak V.J. \& Provencio P.P., 2001 - By-product materials related to $\mathrm{H}_{2} \mathrm{~S}-\mathrm{H}_{2} \mathrm{SO}_{4}$ influenced speleogenesis of Carlsbad, Lechuguilla, and other caves of the Guadalupe Mountains, New Mexico. Journal of Cave and Karst Studies, 63: 23-32.

Provencio P.P. \& Polyak V.J., 2001 - Iron oxide-rich filaments: possible fossil bacteria in Lechuguilla Cave, New Mexico. Geomicrobiology Journal, 18: 297-309. http://dx.doi.org/10.1080/01490450152467804

Queen J.M., 1994 - Speleogenesis in the Guadalupes: the unsettled question of the role of mixing, phreatic or vadose sulfide oxidation. In: Sasowsky I.D. \& Palmer M.V. (Eds)., Breakthroughs in karst geomicrobiology and redox geochemistry. Karst Waters Institute, Charles Town, West Virginia, Special Publication 1: 64-65.

Queen J.M., 2009a - Brine mixing as an initial stage of speleogenesis. In: Palmer A.N. \& Palmer M.V. (Eds)., Caves and karst of the USA. Huntsville, Alabama: National Speleological Society: 280-282.

Queen J.M., 2009b - Post-drainage evolution of the caves of the Guadalupe Mountains, southeastern New Mexico and West Texas, USA. In: White, W.B. (Ed)., Proceedings of 15th International Congress of Speleology, Kerrville, Texas: International Union of Speleology, 2 (2): 964-970.

Queen J.M. \& Melim L.A., 2006 - Biothems: biologically influenced speleothems of the Guadalupe Mountains, New Mexico USA. New Mexico Geological Society Guidebook to $57^{\text {th }}$ Annual Field Conference: 167-173.

Riding R., 2000 - Microbial carbonates: the geological record of calcified bacterial-algal mats and films. Sedimentology, 47 (Supplement 1): 179-214. http://dx.doi.org/10.1046/j.1365-3091.2000.00003.x

Sarbu S.M. \& Lascu C., 1997 - Condensation corrosion in Movile Cave, Romania. Journal of Cave and Karst Studies, 59: 99-102.

Scholle P.A. \& Ulmer-Scholle D.S., 2003 - A color guide to the petrography of carbonate rocks: grains, textures, porosity, diagenesis. American Association of Petroleum Geologists, AAPG Memoir, 77: 474 p.

Spilde M.N., Northup D.E., Boston P.J., Schelble R.T., Dano K.E., Crossey L.J. \& Dahm C.N., 2005 - Geomicrobiology of cave ferromanganese deposits: a field and labratory investigation. Geomicrobiology Journal, 22: 99-116. http:/ /dx.doi.org/10.1080/01490450590945889

Thrailkill J., 1968, Dolomite cave deposits from Carlsbad Caverns. Journal of Sedimentary Petrology, 38: $141-145$.

Turin H.J. \& Plummer M.A., 2000 - Lechuguilla cave pool chemistry, 1986-1999. Journal of Cave and Karst Studies, 62: 135-143.

Wright D.T. \& Wacey D., 2004 - Sedimentary dolomite: a reality check. In: Braithwaite C.J., Rizzi G. \& Darke G. (Eds)., The geometry and petrogenesis of dolomite hydrocarbon reservoirs. Geological Society of London, Special Publication 235: 65-74.

Zheng Y.-F., 1999 - Oxygen isotope fractionation in carbonate and sulfate minerals. Geochemical Journal, 33: 109-126.

http://dx.doi.org/10.2343/geochemj.33.109 
Appendix 1. Identification of samples in Fig. 1, showing approximate composition (from X-ray diffraction and EDS). Calcite, aragonite = $\mathrm{CaCO}_{3}$; dolomite $=\mathrm{CaMg}\left(\mathrm{CO}_{3}\right)_{2}$; huntite $=\mathrm{CaMg}_{3}\left(\mathrm{CO}_{3}\right)_{4} ;$ hydromagnesite $=\mathrm{Mg}_{5}\left(\mathrm{CO}_{3}\right)_{4}(\mathrm{OH})_{2} \cdot 4 \mathrm{H}_{2} \mathrm{O} ;$ quartz $=\mathrm{SiO}_{2}$.

\begin{tabular}{|c|c|c|c|c|c|c|c|}
\hline Sample & & & Composit & $n(\%)$ & & & Description \\
\hline & calcite & aragonite & dolomite & huntite & $\begin{array}{l}\text { hydro- } \\
\text { magnesite }\end{array}$ & quartz & \\
\hline CB 801 & & & 72 & & & 28 & finely crystalline precipitate after aragonite \\
\hline CB 803 & 100 & & & & & & finely crystalline precipitate \\
\hline CB 808 & & & 60 & & & 40 & finely crystalline precipitate \\
\hline CB 813 & 100 & & & & & & corroded winged vent \\
\hline CB 822c & 100 & & & & & & bedrock alteration rind \\
\hline CB 831 & & & 97 & & & 3 & popcorn \\
\hline CB 839 & 25 & & 75 & & & & finely crystalline precipitate with sepiolite \\
\hline CB 841c & 94 & & & & & 6 & corroded bedrock \\
\hline CB 842a & 85 & & 15 & & & & botryoids \\
\hline CB 842b & & 51 & 49 & & & & botryoids \\
\hline CB 845 & & & 97 & & & 3 & finely crystalline blister \\
\hline CB 853 & & 10 & & & 90 & & finely crystalline precipitate bordering pool \\
\hline CB 855 & & 100 & & & & & finely crystalline precipitate bordering pool \\
\hline CB 857 & & 10 & 90 & & & & finely crystalline precipitate in pool \\
\hline CB 903 & 41 & 8 & 51 & & & & finely crystalline precipitate after aragonite \\
\hline CB 905 & 9 & & 89 & & & 2 & finely crystalline precipitate around drip cone \\
\hline CB 909 & & & 100 & & & & finely crystalline precipitate \\
\hline CB 915a & 92 & & 8 & & & & finely crystalline precipitate (top) \\
\hline CB 915b & 97 & & 3 & & & & finely crystalline precipitate with sepiolite \\
\hline CB 915c & 95 & & 5 & & & & finely crystalline precipitate with sepiolite \\
\hline CB 915d & 100 & & & & & & finely crystalline precipitate (base) \\
\hline CB 917b & 5 & 9 & & & 86 & & drip cone \\
\hline CB 932 & 90 & 10 & & & & & subaerial rim \\
\hline CB 934b & & 100 & & & & & botryoids \\
\hline CW 15 br & 100 & & & & & & bedrock, Mammoth Cave \\
\hline CW 15b & 100 & & & & & & weathered rind on bedrock, Mammoth Cave \\
\hline CW347br & 100 & & & & & & bedrock containing pyrite, Mammoth Cave \\
\hline CW347c & 100 & & & & & & bedrock rind around pyrite, Mammoth Cave \\
\hline LG 62 & & & 100 & & & & finely crystalline precipitate \\
\hline LG 212 & & & 100 & & & & bedrock alteration rind \\
\hline LG 344 & 86 & & & & & 14 & glassy crystals \\
\hline LG 357a & 3 & & 97 & & & & finely crystalline precipitate \\
\hline LG 357b & & & 100 & & & & finely crystalline precipitate \\
\hline LG 801 & 9 & & 66 & & & 25 & finely crystalline blister \\
\hline LG 805 & & & 100 & & & & mammillary crust \\
\hline LG 805br & 100 & & & & & & limestone bedrock \\
\hline LG 805a & 17 & & 80 & & & 3 & botryoidal basin fill \\
\hline LG 805b & & & 100 & & & & basin fill \\
\hline LG 805c & 40 & & 60 & & & & basin fill \\
\hline LG 813a & & & 90 & 10 & & & finely crystalline pool precipitate \\
\hline LG 813b & & & 10 & 90 & & & finely crystalline pool precipitate \\
\hline LG 819 & & & 100 & & & & bedrock alteration rind \\
\hline LG 847 & 11 & & 89 & & & & mammillary crust \\
\hline SP 808a & 100 & & & & & & stalactite, corroded rind \\
\hline SP $808 b$ & 100 & & & & & & stalactite, recrystallized interior \\
\hline
\end{tabular}

